Rev. Estud. Ling., Belo Horizonte, aop14854.2019

\title{
O papel dos marcadores prosódicos na fluência de leitura
}

\section{The role of prosodic markers in reading fluency}

\author{
Alcione de Jesus Santos \\ Universidade Federal de Minas Gerais (UFMG), Belo Horizonte, Minas Gerais /Brasil \\ alcionejs@yahoo.com.br \\ Vera Pacheco \\ Universidade Estadual do Sudoeste da Bahia (UESB), Vitória da Conquista, Bahia / \\ Brasil \\ vera.pacheco@gmail.com \\ Marian dos Santos Oliveira \\ Universidade Estadual do Sudoeste da Bahia (UESB), Vitória da Conquista, Bahia / \\ Brasil \\ mdsoliveira@gmail.com
}

Resumo: A escrita conta com recursos gráficos como marcadores prosódicos gráficos e marcadores prosódicos lexicais que indicam aspectos melódicos e rítmicos para o leitor (CAGLIARI, 2002a, 2002b; CHACON, 1998). O leitor fluente deve necessariamente recuperar, em sua leitura, esses aspectos prosódicos (SHREIBER, 1991; KUHN et al., 2003; BREZNITZ, 2006). Portanto, a prosódia é vista como uma característica que deve ser considerada para constatar a fluência. Nosso objetivo foi caracterizar a leitura em voz alta de leitores em diferentes níveis de ensino: leitores do $2^{\circ}$ ano de ensino primário, leitores do $2^{\circ}$ ano de ensino médio; leitores com nível de graduação, a fim de entender a relação entre a fluência de leitura e questões prosódicas. Preparamos um design experimental, no qual controlamos as frases-alvo sob o impacto de marcadores prosódicos. Preparamos duas condições experimentais: uma para o marcador prosódico lexical "perguntou" e uma para o marcador prosódico lexical "disse". Através do Praat, medimos os valores da frequência fundamental de todas as sílabas tônicas das frases-alvo e extraímos as curvas melódicas das frases-alvo. Os resultados mostram que a capacidade de recuperar aspectos prosódicos incitados em texto por marcadores prosódicos são diretamente proporcionais aos níveis de escolaridade.

Palavras-chave: fluência de leitura; leitura e escrita; marcadores prosódicos. 


\begin{abstract}
Writing has graphic resources such as graphic and lexical prosodic markers that indicate melodic and rhythmic aspects to the reader. (CAGLIARI, 2002a, 2002b); CHACON, 1998). The skilled reader must necessarily recover, in her/his reading, these prosodic aspects. Therefore, prosody is seen as a feature that should be considered during reading evaluation in order to check reading fluency. (SHREIBER, 1991; KUHN, 2003 et al.; BREZNITZ, 2006). This paper aims to characterize reading aloud of readers at different levels of education: readers on the 2 nd year of primary education, readers on the $2^{\text {nd }}$ year of high school and readers at the college undergraduate level in order to understand the relationship between reading fluency and prosodic issues. An experimental design was set, in which we control target phrases under the impact of prosodic markers. We also prepared two experimental conditions: one for the lexical prosodic marker "asked" and another for the lexical prosodic marker "said". Through Praat we measured the values of fundamental frequency of all the tonic syllables of the target sentences and extracted the melodic curves of the target phrases. The results show that the ability to recover prosodic aspects brought about in text by prosodic markers is directly proportional to levels of education.
\end{abstract}

Keywords: reading fluency; reading and writing; prosodic markers.

Recebido em 06 de fevereiro de 2019

Aceito em 19 de maio de 2019

\title{
Introdução
}

No processo de leitura, estão envolvidos mecanismos complexos como decodificação e compreensão de sinais gráficos que comportam aspectos sintáticos e semânticos. Dentre os aspectos envolvidos no desempenho da leitura, destaca-se a prosódia que, segundo Cagliari (2002a, 2002b), mais que a função de enfeitar o texto, exerce função fundamental de tornar o texto compreensível.

Autores como Shreiber (1991), Kuhn et al. (2003) e Breznitz (2006) defendem os aspectos prosódicos no desempenho da leitura quanto à relevância destes na compreensão do material lido. Assim, leitores capazes de utilizar os aspectos prosódicos de forma apropriada apresentam uma leitura mais fluida, expondo características de expressividade da linguagem oral somadas à precisão, velocidade e compreensão podem ser considerados leitores fluentes.

Um texto escrito conta com recursos gráficos como Marcadores Gráficos (MG) e marcadores prosódicos lexicais (MPLs) que direcionam 
o leitor para o modo de procedência com as variações melódicas e entoacionais da passagem que estão sob o escopo dessas marcas gráficas. (CAGLIARI, 2002a, 2002b; PACHECO, 2006). Como a finalidade do texto escrito é a leitura, quer silenciosa quer em voz alta, um leitor fluente deverá ser capaz de, necessariamente, recuperar e apresentar (na produção de leitura) e recuperar mentalmente (na leitura silenciosa), esses aspectos prosódicos.

Conforme Cagliari (1989), para que a leitura de um texto escrito seja de fato significativa, é necessária procedência adequada com as variações melódicas e entoacionais incitadas por marcadores.

Partindo do pressuposto de que quanto maior for a experiência e maior o hábito de leitura do leitor, mais marcada prosodicamente será a sua leitura, espera-se que um bom leitor apresente variações prosódicas satisfatórias desencadeadas por marcadores prosódicos.

Nosso objetivo foi avaliar a leitura em voz alta de textos ricos em marcadores prosódicos realizada por indivíduos estudantes das séries iniciais, iniciando o contato com a leitura; estudantes em séries mais avançadas; e indivíduos formados, a fim de confirmar ou não a hipótese de que leitores mais escolarizados (fluentes) resgatam, mais satisfatoriamente, aspectos prosódicos desencadeados pela presença de marcadores prosódicos gráficos e marcadores prosódicos lexicais.

\section{Prosódia e fluência de leitura}

Atualmente, há estudos preocupados em investigar questões relacionadas à fluência de leitura atrelada a uma realização prosódica adequada como sendo essencial à compreensão, haja vista que a fluência na leitura é uma das habilidades necessárias para que compreensão do sentido de um texto ocorra (LEITE, 2012; BREZNITZ, 2006; HUDSON; LANE; PULLEN, 2005). Quando falamos sobre a relação entre prosódia e compreensão de leitura, de qualquer modo, estamos pensando na compreensão daquele que lê, mas também daquele que ouve a leitura. Assim, o leitor fluente, no ato da leitura, deverá lançar mão do gerenciamento adequado dos recursos prosódicos a fim de transmitir os mais variados tipos de informação (sintático-semântico-discursivas), destacar constituintes importantes dentro dos enunciados etc. Uma leitura que traz essas características revela, quase sempre, que o leitor compreendeu as relações estabelecidas entre as estruturas complexas 
que compõem o texto - o que de algum modo - demonstra certo grau de compreensão, exceto quando se trata de um texto cujo conteúdo seja desconhecido pelo leitor, a ponto de ele não ter nenhum conhecimento prévio que possa auxiliá-lo na compreensão do material lido.

Sendo assim, diante de uma leitura que traz uma cadência apropriada, o ouvinte é capaz de lançar mão do seu modelo de fala para articular, inferir e compreender o conteúdo da mensagem que está sendo veiculada pelo leitor. Para isso, assim como o leitor, o ouvinte também deve ter, em certa medida, conhecimentos prévios sobre o assunto da leitura que sustentem a sua compreensão.

Wennerstrom (2000), partindo de uma análise de diálogos informais entre falantes nativos e não-nativos do inglês, avalia o contributo das propriedades prosódicas para a caracterização da fluência discursiva. Os resultados do seu estudo apontam que os falantes considerados mais fluentes produzem o seu discurso respeitando a coerência e coesão dos constituintes prosódicos e produzem tons de fronteira que indicam a continuação discursiva.

Uma pesquisa realizada por Ferreira (2009) avaliou a fluência de leitura em crianças com e sem necessidades educativas especiais, estudantes do $2^{\circ}$ ano, levando em consideração a utilização das pausas, bem como o uso adequado das entonações - o uso das vírgulas, dos pontos finais, reticências, dois pontos, travessão, ponto de interrogação e ponto de exclamação.

Fussek (2009) investigou a importância dos aspectos prosódicos para a compreensão da linguagem oral e da leitura. Apresentando um texto (com e sem variação prosódica) para uma turma do $3^{\circ}$ ano do ensino fundamental, seguidos de dois questionários sobre texto lido, a pesquisadora concluiu que há correlação entre o desempenho dos participantes na compreensão da escuta (com e sem prosódia) e o desempenho na compreensão da leitura.

Se a leitura em voz alta de modo fluente estiver atrelada à marcação da prosódia adequada, de forma coerente, realizando as pausas nos momentos apropriados, as curvas ascendente e descendente da entonação, as chances de a compreensão do texto lido ocorrer de forma rápida e precisa serão maiores. O contrário ocorrerá se a leitura em voz alta desconsiderar o modo de procedência anteriormente citado. Nesse caso, a leitura tende a ser mais lenta de modo que a atenção se voltará para a decodificação, comprometendo, assim, a compreensão do material lido. 
A falta de marcação prosódica adequada em uma leitura em voz alta é com frequência encontrada nos primeiros estágios de aquisição de leitura. Nessa fase, é comum a criança decifrar o texto de modo lento, na maioria das vezes, negligenciam as marcas de pontuação de modo que a variação prosódia encontra-se comprometida. Esse fato interfere significativamente na construção do sentido do texto lido. Contudo, a partir do aprimoramento e desenvolvimento da habilidade de leitura, a criança torna-se mais fluente, exceto crianças com algum distúrbio de leitura.

Considerando que a escrita conta com recursos gráficos que são capazes de representar aspectos suprassegmentais da fala, a leitura de um texto deve, pois, apresentar variações de volume, de velocidade de fala e de entoação típicas da linguagem oral. Além disso, a recuperação das marcas prosódicas presentes no texto escrito é extremamente importante para a compreensão do discurso que está sendo veiculado. Assim sendo, creditamos que um leitor escolarizado é mais apto para compreender um texto escrito porque consegue, com mais facilidade, apresentar na leitura aspectos suprassegmentais responsáveis pela organização discursiva como, por exemplo, as pausas, ritmo, grupos tonais, velocidade de fala, volume e qualidade de voz. Conforme Cagliari (1989), do ponto de vista do sistema escrito, o ato da decodificação das palavras na leitura é muito importante. Contudo, na leitura, muito mais que decifrar palavras, é necessária a concatenação das palavras em unidades fonológicas, sintáticas, semânticas e discursivas para que se compreenda o conteúdo do texto.

Apesar de não existir um consenso na sua definição, o conceito de fluência de leitura já vem considerando os aspectos prosódicos. Percebese que a prosódia - aspecto integrante da fluência de leitura - constitui uma condição para a leitura eficaz. Sendo desse modo, a fluência atrelase à automatização, prosódia e compreensão. As discussões dos autores citados neste trabalho convergem no sentido de que a adequação da variação de prosódia durante a leitura é um indicador de sua competência leitora.

\subsection{Os marcadores prosódicos gráficos/sinais de pontuação - MPG}

Os sinais de pontuação têm, na escrita, usos e funções bastante diversificadas (PACHECO, 2008). Desde os escritos do grego antigo 
vê-se o uso dos sinais de pontuação, sobretudo o uso dos sinais que diferenciam as interrogativas e afirmativas (CAGLIARI, 1995).

$\mathrm{O}$ uso dos sinais de pontuação justifica-se tanto por razões sintáticas quanto por razões prosódicas já que, como propõe Cagliari (2002a, 2002b), os sinais de pontuação referem-se, quase sempre, a atos sintáticos que apresentam um padrão prosódico próprio, como as frases afirmativas, interrogativas.

Por essa razão é que os gramáticos tradicionais atribuem o uso dos sinais de pontuação à tentativa de reprodução das pausas, cadências, ritmo, entonação e as melodias da fala (PACHECO, 2003). Para esta autora, as normas propostas pelos gramáticos tradicionais para os usos dos sinais de pontuação estão estritamente ligadas à sintaxe ou à semântica, embora sejam uma tentativa de representação dos aspectos da língua falada.

Chacon (1998) desenvolveu estudos importantes a respeito de um ritmo da escrita. Para ele, a escrita, assim como a fala, possui um ritmo próprio, determinado pelo uso de sinais de pontuação. Além disso, o recurso da pontuação atrela-se à expressão do escrevente e à espacialização da linguagem, simultaneamente em várias dimensões: (a) na dimensão fônica, associada a pausas, contornos entoacionais, intensidade e duração; (b) na dimensão sintática, associada à delimitação de unidades; (c) na dimensão textual, indicada como a responsável pela organização e coerência textual; (d) na dimensão enunciativa, ligada à expressividade do escrevente no código semiótico. Todas essas dimensões estão organizadas de forma não isomórfica, unidas por meio da enunciação ao ritmo da escrita e, juntas, formam o aspecto multidimensional da linguagem.

Para Corrêa (2004), há uma prosódia presente na circulação do escrevente pela imagem que ele faz da gênese da escrita. Na concepção desse autor, a prosódia aparece na escrita somente através da articulação com outros planos como o léxico e a sintaxe, por exemplo. Além disso, quase sempre, a leitura de um texto escrito é feita mediante a imposição, quer seja em voz alta quer não (considerando que, na leitura silenciosa, o leitor recupera, ainda que mentalmente, os aspectos prosódicos), de uma prosódia. Nesse sentido, a prosódia não é única e exclusivamente da fala, haja vista que se constitui como exigência da leitura, demarcada, também, pelo uso dos sinais de pontuação. Ademais, o leitor poderá, perfeitamente, 
recuperar a prosódia por meio de diferentes pistas linguísticas deixadas pelo escrevente. (CORRÊA, 2004, p. 116)

Dentre os estudiosos que atribuem aos sinais de pontuação a importância na organização sintática, semântica, bem como na representação das variações da fala, destacam-se Kondo e Mazuka (1996); Cohen et al (2001) que veem os sinais de pontuação como sendo análogos visuais da prosódia. Teóricos como Baldwin e Coady, (1978), Chen et al. (1988) atribuem à pontuação a função de organizadora da sintaxe. Estudiosos como Cagliari (1995) entendem os sinais de pontuação enquanto marcas de coerência e coesão. Chacon (1998) classifica os sinais de pontuação como delimitadoras de unidades rítmicas.

Cagliari (1989) apresenta a hipótese de que os sinais de pontuação funcionam como marcadores prosódicos. Essa hipótese é reafirmada por Cagliari (2002a, 2002b) quando apresenta uma descrição prosódica dos principais sinais de pontuação do português brasileiro. Os trabalhos de Cagliari apontam que a presença de um sinal de pontuação tende a incitar variações prosódicas.

Os trabalhos de Pacheco (2003) endossam as considerações de Cagliari (1989, 2002a, 2002b) acerca dos marcadores prosódicos da escrita. A pesquisadora desenvolve estudo no qual caracteriza acusticamente os sete sinais de pontuação mais comuns do português brasileiro quais sejam: dois pontos, interrogação, ponto e vírgula, reticências, ponto final, exclamação e ponto final. Com base na leitura oral de seis informantes, a autora encontra variações de F0, intensidade, duração e pausa nos componentes tônico e pretônico nas frases que aparecem sob incidência dos sinais de pontuação por ela investigados. As conclusões às quais Pacheco (2003) chega são de que os sinais de pontuação podem ter características acústicas particulares, de modo a se diferenciarem entre si.

Em linhas gerais, os sinais de pontuação têm funções diversas e influenciam sob diferentes aspectos a organização da linguagem escrita. Eles se constituem como marcas sintático-prosódico-discursivas que contribuem para a organização e compreensão do texto escrito. Levando em conta que a finalidade do texto escrito é a leitura, esta deve, pois, recuperar informações importantes que são introduzidas no texto pelo uso dos sinais de pontuação. Um leitor fluente deverá ser capaz de gerenciar a sua leitura, quer em voz alta, quer silenciosa, recuperando aspectos da fala oral importantes para a compreensão do que está sendo lido. 


\subsubsection{Os marcadores prosódicos lexicais - MPLs}

As diversas situações comunicativas em que o falante está inserido cotidianamente exigem dele uma intenção comunicativa, fazendo-o lançar mão de escolhas de ordem sintagmática e paradigmática (PACHECO, 2006).

De acordo com Reis (2001, p. 223), “a entonação desempenha papel fundamental no ato de comunicação linguística através da manifestação de atitudes de falantes". Sendo assim, a entonação exerce um papel importante na atribuição da carga semântica à atitude dos falantes. Pode-se dizer, então, que a entonação nos permite aferir atitudes do falante como polidez, autoritarismo, arrogância, tristeza, alegria etc. A atitude do falante se distingue, pois, da emoção que se trata de um comportamento adotado e controlado pelo falante, com implicações morais e intelectuais como, por exemplo, a reprovação, a justificativa e a ironia (FÓNAGY, 1993).

Conforme Fónagy (1993), o próprio ato comunicativo exige que o falante apresente em sua fala variações entoacionais como as sentenças interrogativas e exclamativas, por exemplo. Encontramos, ainda, nas situações comunicativas do dia a dia, variações entoacionais que não são controladas pelos falantes. Estas, por sua vez, são reflexos da tensão psíquica: cólera, alegria, tristeza, manifestadas inconscientemente na fala. De acordo com o autor supracitado, essas variações melódicas presentes nas situações comunicativas, decorrentes das atitudes do falante, a saber, da modalização e da emoção, são variações prosódicas que podem também ser registradas na escrita através de expressões semânticas que fazem referência à prosódia da língua, já que estas atitudes, emoções e modos de dizer requerem um modo de procedência do ponto de vista fonético. A respeito de tais expressões Cagliari (2002a, p. 7) pontua que:

Caracterizam atitudes do falante, emoções e modos de dizer que fazem uma referência à prosódia da língua, uma vez que tais atitudes, emoções e modos de dizer precisam ser realizados foneticamente de uma determinada maneira e não de outra (CAGLIARI, 2002a, p. 7).

Embasada nas discussões de Cagliari (2002a, 2002b), Pacheco (2006) considera esses marcadores prosódicos como sendo "entradas lexicais no léxico mental dos falantes", enquanto tal, podem muito 
bem estarem sujeitas ao funcionamento de qualquer unidade lexical e pertencer, por exemplo, a uma classe gramatical.

Entende-se, então, que essas unidades semântico-lexicais de cunho prosódico podem pertencer a categorias gramaticais diversas, podendo ser um, verbo (gritou, sussurrou), adjetivo, advérbio (raivosamente, calmamente), expressões adverbiais (disse baixinho), que são usadas para qualificar prosodicamente o significado de um verbo que se refere ao ato de falar (CAGLIARI, 2002a, 2002b).

A classificação dessas entradas lexicais como marcadores prosódicos deve-se a sua carga semântica, que comporta informações de cunho prosódico, que podem se referir às atitudes do falante: raiva, polidez, autoritarismo, e/ou ritmo, volume. (CAGLIARI, 2002a, 2002b; PACHECO, 2006).

Do ponto de vista de Pacheco (2006), essas referências, na condição de um marcador prosódico do tipo lexical, podem, então, ser consideradas como Marcadores Prosódicos Lexicais (MPLs) portadores tanto de informações da ordem da escrita (na condição de palavras constituídas ortograficamente), quanto de informações da ordem da fala precisamente prosódica (na condição de palavras e/ou expressões cuja carga semântica traz necessariamente informações que remetem a variações prosódicas).

A hipótese apresentada pelos autores supracitados é de que atitudes e emoções podem ser resgatadas na escrita por meio de recursos como os marcadores prosódicos lexicais, por exemplo. Sendo assim, pode-se afirmar que a leitura em voz alta de textos que trazem registrados os marcadores prosódicos lexicais pode ser avaliada observando variações de velocidade de fala, tessitura e volume, desencadeadas por MPLs.

Considerando que a razão de ser do texto escrito é a sua leitura e para que tal leitura seja eficaz é necessário que o leitor proceda adequadamente com os aspectos rítmicos e melódicos indicados no texto por determinadas marcas gráficas (sinais de pontuação, itens lexicais, tipos de letras, formatação do texto etc.) espera-se que leitores fluentes sejam capazes de recuperar na sua leitura as variações melódicas e entoacionais desencadeadas por marcadores prosódicos gráficos e por marcadores prosódicos lexicais.

$\mathrm{Na}$ leitura de um texto, o leitor experiente recupera com facilidade os aspectos prosódicos desencadeados pelos marcadores prosódicos de modo que sua leitura apresenta características e expressividade 
da linguagem oral. Espera-se, portanto, que leitores escolarizados apresentem, na leitura, padrões melódicos e entoacionais mais satisfatórios em detrimento de leitores menos escolarizados.

\section{Considerações sobre entoação}

Um dos propósitos do presente artigo constituiu-se em caracterizar o contorno melódico de frases sob a incidência de diferentes sinais de pontuação introduzidas pelos marcadores prosódicos lexicais "perguntou" e "disse", lidas por crianças estudantes das séries iniciais, estudantes em séries mais avançadas e por indivíduos com nível superior de escolaridade. A nossa hipótese foi a de que os contornos melódicos e entoacionais das frases lidas pelos participantes escolarizados seriam mais compatíveis com o marcador prosódico que lhes antecede e que lhes sucedem. Sendo assim, considerações acerca da entoação tornamse relevantes para descrever e compreender os contornos melódicos das frases produzidas pelos diferentes grupos de leitores aqui investigados.

Em se tratando do aspecto estritamente linguístico, Moraes (1993) define a entoação como sendo responsável por desempenhar funções específicas (sintáticas, semânticas e pragmáticas) no nível da frase.

A entoação é extremamente importante para o processo comunicativo. O falante utiliza-se da entoação, nas suas diversas dimensões, para atribuir e distinguir os mais variados significados à fala que vão desde conteúdos afetivos e emocionais da comunicação a aspectos sociolinguísticos (QUILIS, 1988). Contudo, interessa-nos, aqui, a entoação apenas na sua dimensão linguística, mais especificamente na sua função distintiva das diferentes modalidades de frases, a saber, declarativa ou afirmativa, das frases interrogativas, exclamativas etc.

Dentre as diversas funções da entoação, destaca-se a função modal, responsável por determinar a modalidade da frase, bem como "a força ilocutória que deve ser atribuída ao enunciado" (MORAES, 1993, p. 102).

A literatura relaciona a entoação aos parâmetros acústicos de Frequência Fundamental (F0), intensidade e duração (SCARPA, 1999; FRY, 1976; t'HART; COLLIER; COHEN, 1990). As vibrações das pregas vocais têm como correlato acústico a F0, em termos perceptuais, a altura (SCARPA, 1999). Sendo assim a F0 é o correlato direto do aspecto fonético que a entoação assume nos estudos prosódicos. 
A entoação, então, refere-se à “escala de elevação e abaixamento da voz em uma frase" (MATTOSO CÂMARA, 1977, p. 6). Essa escala à qual se refere Mattoso Câmara nada mais é que as variações de F0 que, ora ascende, ora descende de modo que o contorno melódico é modelado. Essas variações melódicas ocorrem devido às vibrações da pressão do ar na laringe no momento em que a fala é produzida.

As variações de F0 dentro de uma sentença vão determinar se ela se trata de uma afirmativa, interrogativa, exclamativa, ou quaisquer outras. Em se tratando do português brasileiro, a entoação tem a função de discriminar os enunciados afirmativos, interrogativos e exclamativos e/ou outros.

Assim, a configuração do contorno melódico de um enunciado interrogativo está relacionada a suas estruturas sintáticas e lexical. As interrogativas totais para as quais se espera como resposta sim ou não (e que caracterizam os enunciados interrogativos investigados nesse estudo), apresentam proeminência melódica na sílaba tônica final da sentença. Nesse tipo de interrogativas, a altura melódica inicial é um pouco mais baixa, em relação às frases declarativas. No entanto, é o comportamento da sílaba tônica final que vai distinguir as declarativas das perguntas sim ou não (REINECKE, 2007).

Portanto, os enunciados vão diferenciar entre si devido às particularidades do seu contorno melódico. As diferenças que há entre os diferentes tipos de frases são estabelecidas a partir de pontos específicos determinados pela posição da sílaba tônica saliente.

Logo, a entoação fornece diferentes padrões prosódicos para que, tanto o falante quanto o ouvinte, expressem e decodifiquem o que se quer dizer com determinada entoação (SOUZA, 2007, p. 12). Uma mesma frase pode apresentar padrões prosódicos distintos a depender das variações de F0, o que garante à entoação, além do papel semântico e fonológico, o sintático.

Segundo Massini-Cagliari e Cagliari (2001, p. 117), os diferentes tipos de enunciados do português "carreiam padrões melódicos que são determinados pelo sistema". Desse modo, as frases afirmativas vão se diferenciar das frases interrogativas quanto às variações das curvas melódicas: enquanto as frases interrogativas apresentam padrões melódicos ascendentes - em que as frequências aumentam ao longo da sentença, as frases afirmativas apresentam padrões melódicos descendentes - em que a frequência dos sons diminui ao longo da sentença. 
Conforme Mateus et al. (1994), além das sentenças afirmativas e exclamativas, há os enunciados imperativos por meio dos quais exprimese uma certeza, uma conclusão ou uma ordem nos quais se observa variação de F0 no sentido descendente.

Além dos contornos melódicos ascendente e descendente, há também o contorno melódico plano em que não há modificação perceptível ao longo da sentença. Pacheco (2003), em estudo no qual avaliou o padrão prosódico dos principais sinais de pontuação do português brasileiro, verificou que enunciados finalizados pelas reticências tendem a apresentar um contorno melódico nivelado, sem alterações na curva entoacional.

O contorno melódico gerado pela elevação e abaixamento da F0 em uma sentença é importante porque permite aos interlocutores de uma interação discursiva captar tanto a modalidade quanto a intenção subjacentes a uma sentença lida ou pronunciada. Sendo assim, considerando que os valores de F0 determinam a curva melódica responsável pelo estabelecimento do significado, a questão que trazemos para esta pesquisa é: variações de F0 compatíveis com a modalidade (interrogativa, afirmativa, exclamativa, neutra) estabelecida para as sentenças por meio dos MPGs e MPLs podem caracterizar leitores quanto à fluência e à compreensão textual? No intuito de caracterizar leitores fluentes e não fluentes quanto à capacidade de resgatar variações prosódicas do texto escrito incitadas por marcas gráficas, bem como quanto à capacidade de compreensão textual, este trabalho avaliou as variações da $\mathrm{F} 0$ em sentenças produzidas por leitores em processo de escolarização (grupo I e II) e leitores formados (grupo III).

\section{Materiais e métodos}

\subsection{Seleção dos participantes}

Para a seleção dos participantes do grupo I - estudantes do $2^{\circ}$ ano do ensino fundamental - foi necessária uma seleção prévia dada a dificuldade de leitura que leitores dessa faixa de escolaridade apresentam. Para a seleção dos participantes da pesquisa, optamos por escutar a leitura do texto "O Palhaço" realizada por seis colegiais para observar se apresentavam um nível de domínio de leitura satisfatório para a observação das variáveis propostas na primeira etapa desse estudo, 
quais sejam, a velocidade e precisão de leitura para avaliar a fluência de leitura. A escolha do texto "O palhaço" deveu-se por se tratar de um texto com sintaxe simples, com grau de dificuldade de leitura compatível com a seriação escolar do grupo I. Foram excluídos os indivíduos que apresentaram um nível de leitura lentificado e/ou silabado. O texto o palhaço somente foi usado para seleção dos participantes do grupo I. Diante desse critério, buscando compor o grupo com quatro participantes, dois homens e duas mulheres; excluímos dois dos seis alunos avaliados que apresentaram uma leitura lenta e silabada. Todos os participantes desse grupo tinham idade de sete anos.

O grupo II - leitores estudantes do $2^{\circ}$ ano do ensino médio - foi composto de quatro jovens, sendo dois homens e duas mulheres com idade entre 15 e 17 anos.

O grupo dos leitores com nível superior de escolaridade, que constitui o grupo III, foi composto de dois homens e duas mulheres com idade entre 30 e 44 anos.

Participaram, então, 12 indivíduos - seis homens e seis mulheres.

\subsection{Procedimentos para seleção dos marcadores prosódicos lexicais}

\subsubsection{MPL "Perguntou" e MPL "Disse"}

A escolha desses dois marcadores deve-se ao fato de serem dois extremos - enquanto o marcador "perguntou" tem dupla face, ao mesmo tempo em que carrega uma carga semântica, traz também uma informação prosódica que remete a um enunciado interrogativo, o marcador lexical "disse" é neutro, isto é, a sua natureza não traz nenhuma informação prosódica específica. Trata-se, pois, de um verbo dicendi que pode introduzir perfeitamente, as mais diferentes modalidades de frases. Com isso, o nosso objetivo foi saber se, diante de um MPL como "disse" que não incita um comportamento prosódico específico o leitor menos experiente é capaz de organizar as variações prosódicas de modo que sejam compatíveis com o MPG que finaliza a frase. Além disso, a escolha pelo marcador "perguntou" nos possibilitou verificar em que medida leitores experientes são capazes de, a partir da presença do MPL "perguntou”, modelarem sua leitura em tom ascendente (típico dos enunciados interrogativos) ainda que as frases não sejam finalizadas pelo ponto de interrogação correspondente ao MPG "perguntou". 


\subsubsection{Seleção dos marcadores prosódicos gráficos}

Partindo das constatações de Cagliari (1989, 2002a, 2002b), bem como de Pacheco $(2003,2006,2008)$ as quais evidenciam que as variações melódicas da fala podem ser representadas na escrita por meio de marcas gráficas, selecionamos, neste trabalho, como objeto de investigação, os sinais de pontuação: exclamação, interrogação, ponto final, reticências por se tratarem dos sinais de pontuação mais usuais na escrita do português brasileiro.

\subsubsection{Seleção e produção das frases-alvo}

Foram criadas três frases para serem utilizadas sob a incidência dos MPLs e dos MPGs, como segue:

QUADRO 1 - Frases usadas sob a incidência dos MPL e dos MPGs

Frase 1 - Isso é tudo o que vossa majestade quer

Frase 2 - É tudo o que eu preciso fazer

Frase 3 - Vossa majestade acredita mesmo nisso

Frase 4 - É possível sair dessa vida

Todas as frases-alvo ocorrem, nas condições da presença do MPL/ DISSE e MPL/PERGUNTOU, seguidas dos MPGs: (?),(!), (...), (.), (s/p sem pontuação), conforme disposto no quadro 2, seguinte:

QUADRO 2 - combinações dos MPL com os respectivos MPGs investigados

\begin{tabular}{|c|c|c|c|c|c|c|}
\hline $\mathrm{MPL}^{2} /$ Disse & Frase-alvo & $\mathrm{MPG}^{3} / ?$ & & $\mathrm{MPL}^{2} /$ Perguntou & Frase-alvo & $\mathrm{MPG}^{3} / ?$ \\
\hline $\mathrm{MPL}^{2} /$ Disse_ & Frase-alvo & $\mathrm{MPG}^{3} / !$ & & $\mathrm{MPL}^{2} /$ Perguntou & Frase-alvo & $\mathrm{MPG}^{3} / !$ \\
\hline $\mathrm{MPL}^{2} /$ Disse & Frase-alvo & $\mathrm{MPG}^{3} / \ldots$ & & $\mathrm{MPL}^{2} /$ Perguntou & Frase-alvo & $\mathrm{MPG}^{3} / \ldots$ \\
\hline $\mathrm{MPL}^{2} /$ Disse & Frase-alvo & $\mathrm{MPG}^{3} /$. & $\mathrm{MPL}^{2} /$ Perguntou & Frase-alvo & $\mathrm{MPG}^{3} /$. \\
\hline $\mathrm{MPL}^{2} /$ Disse & Frase-alvo & $\mathrm{S}^{1} \mathrm{P}^{1}$ & & $\mathrm{MPL}^{2} /$ Perguntou & Frase-alvo & $\mathrm{S}^{1} \mathrm{P}^{1}$ \\
\hline
\end{tabular}

Fonte: elaboração própria.

Obs 1: S/P: sem pontuação; 2: MPL: marcador prosódico lexical; 3: MPG: marcador prosódico gráfico; $\mathrm{S} / \mathrm{P}:$ sem pontuação. 
Sendo assim, os informantes foram expostos basicamente a duas condições experimentais:

Condição 1, na qual os informantes eram expostos aos textos com frases-alvos introduzidas pelo marcador prosódico "perguntou", e finalizadas ora por ponto de exclamação, ora por ponto final, ora por ponto de interrogação, ora por reticências. Nessa condição, houve uma coincidência entre variação melódica da frase-alvo e o marcador prosódico anunciado antes da frase-alvo quando esta era finalizada pelo ponto de interrogação. Quando as frases-alvos ocorriam nesse contexto, elas traziam informações prosódicas de uma sentença interrogativa tanto do marcador prosódico lexical quanto do marcador prosódico gráfico. Nesse caso, foi possível verificar se houve um aumento na recuperação de aspectos prosódicos prototípicos quando MPL E MPG são coincidentes.

Quando as frases ocorriam nos demais contextos, finalizadas por sinais de pontuação não coincidentes com o marcador prosódico perguntou, elas carregavam informações prosódicas tanto do MPL quanto do MPG que são diferentes entre si. Essas ocorrências possibilitaram verificar qual é a estratégia utilizada pelos diferentes leitores, isto é, se diante de marcadores prosódicos com cargas prosódicas diferentes o que prevalece é a variação incitada pelo MPL ou pelo MPG.

Condição 2, na qual os informantes eram expostos aos textos com frases-alvos introduzidas pelo marcador prosódico disse, e finalizadas ora por ponto de exclamação, ora por ponto final, ora por ponto de interrogação, ora por reticências. Nessa condição, em que o marcador prosódico lexical que antecede a frases-alvo é neutro, não carregando informações prosódicas, foi possível verificar a capacidade dos diferentes grupos de leitores de resgatarem as variações prosódicas típicas de ponto de interrogação, exclamação, ponto final, reticências das frases investigadas.

As condições experimentais apresentadas no quadro 2, bem como as ocorrências das combinações dos diferentes MPLs com os respectivos MPGs permitiram compreender o comportamento dos diferentes grupos de leitores, aqui investigados, com as variações melódicas incitadas por marcadores prosódicos.

No quadro 3 constam exemplos de ocorrências das combinações dos diferentes MPLs com os respectivos MPGs. 
QUADRO 3 - Exemplos de frases-alvo sob incidência dos PMLs e MPGs

\begin{tabular}{|c|c|c|c|c|c|}
\hline MPL/Disse & Frase-alvo & MPG/? & MPL/Perguntou & Frase-alvo & MPG/? \\
\hline \multicolumn{3}{|c|}{$\begin{array}{l}\text { A rosa com muito ódio DISSE: } \\
\text { - Vossa majestade acredita mesmo nisso? }\end{array}$} & \multicolumn{3}{|c|}{$\begin{array}{l}\text { A rosa com muito ódio PERGUNTOU: } \\
\text { - Vossa majestade acredita mesmo nisso? }\end{array}$} \\
\hline MPL/Disse_ & Frase-alvo & MPG/! & MPL/Perguntou & Frase-alvo & MPG/! \\
\hline \multicolumn{3}{|c|}{$\begin{array}{l}\text { A rosa em soluços sorriu para o Cravo e } \\
\text { DISSE: } \\
\text { - É possível sair dessa vida! }\end{array}$} & \multicolumn{3}{|c|}{$\begin{array}{l}\text { A rosa em soluços sorriu para o Cravo e } \\
\text { PERGUNTOU: } \\
\text { - É possível sair dessa vida }\end{array}$} \\
\hline MPL/Disse & Frase-alvo & MPG/... & MPL/Perguntou & Frase-alvo & MPG/... \\
\hline \multicolumn{3}{|c|}{$\begin{array}{l}\text { E quase decidida a visitar o cravo, para si } \\
\text { DISSE: } \\
\text { - É tudo o que eu preciso fazer... }\end{array}$} & \multicolumn{3}{|c|}{$\begin{array}{l}\text { E quase decidida a visitar o cravo, para si } \\
\text { PERGUNTOU: } \\
\text { - É tudo o que eu preciso fazer... }\end{array}$} \\
\hline MPL/Disse & Frase-alvo & MPG/. & MPL/Perguntou & Frase-alvo & MPG/. \\
\hline \multicolumn{3}{|c|}{$\begin{array}{l}\text { Desejando amolecer o coração do cravo } \\
\text { DISSE: } \\
\text { - Isso é tudo que Vossa Majestade quer. }\end{array}$} & \multicolumn{3}{|c|}{$\begin{array}{l}\text { Desejando amolecer o coração do cravo } \\
\text { PERGUNTOU: } \\
\text { - Isso é tudo que Vossa Majestade quer. }\end{array}$} \\
\hline
\end{tabular}

\subsubsection{Seleção e produção dos textos}

Foram elaborados três textos para serem inseridas as frases-alvos sob incidência dos MPGs e MPLs, nas situações descritas no quadro 3. Escolhemos três narrativas conhecidas da literatura infantil, a saber, Branca de Neve, O Cravo e a Rosa e A Cigarra e a Formiga. Criamos uma versão para cada uma dessas narrativas. Feito isso, elaboramos, para cada uma dessas narrativas, nove versões com pequenas mudanças em cada uma. Sendo assim, cada narrativa conta com 10 versões, totalizando 30 textos. Inserimos estrategicamente as quatro frases-alvo nessas narrativas de modo que cada combinação aparece três vezes ao longo dos textos. Como forma de padronizarmos o ambiente de ocorrência dos marcadores prosódicos investigados nessa pesquisa, cada um dos três textos possui 10 versões (I, II, III, IV, V, VI, VII. VIII, IX e X). Essas versões apresentam diferenças mínimas entre si as quais se justificam pelas adaptações realizadas nos trechos nos quais foram inseridas as frases-alvo sob a incidência dos diferentes MPLs. Todos os participantes leram todas as versões. 
Em síntese, o corpus desse trabalho contou com três textos distintos, cada um deles com 10 versões, sendo composto, portanto, por 30 textos (15 para a investigação do MPL "perguntou" e os respectivos MPGs (?), (!), (...), (.) e frases sem pontuação, e 15 para a investigação do MPL "disse" e os respectivos MPGs (?), (!), (...), (.). Cada frase-alvo aparece três vezes sob a incidência de um mesmo MPL e mesmo MPG de modo que obtivemos três repetições para cada frase. Tanto o MPL "disse" como o MPL "perguntou" aparece em 15 versões nas 4 frases-alvo analisadas sendo 60 frases-alvo para cada MPL com seus 4 respectivos MPGs portanto. Ao total são 120 ocorrências para cada informante.

\subsubsection{Realização das gravações}

As gravações foram realizadas no Laboratório de Pesquisa e Estudos em Fonética e Fonologia (LAPEFF) da Universidade Estadual do Sudoeste da Bahia (UESB), em uma cabine acústica, utilizando-se o programa Audacity 2.0.5, a uma taxa de amostragem de $44.100 \mathrm{~Hz}$. Foi pedido aos informantes que lessem os textos em voz alta. A cada três versões lidas, foi dada uma pausa de 10 minutos para minimizar o cansaço do informante. As gravações duraram, em média, 1:30h minutos para cada informante.

\subsubsection{Mensuração da Fo}

Transferimos o material coletado para o software Praat 5.0 para análise acústica. Mensuramos a F0 de todas as sílabas tônicas das frases-alvo investigadas. O procedimento foi feito, selecionando a vogal da sílaba tônica e mensuramos o ponto central da mesma, por meio do comando $\mathrm{Ctrl}+0$. Com esse procedimento foi possível avaliar a curva de F0 das sílabas tônicas, bem como verificar o movimento da F0 em todas as sílabas tônicas e, assim, descrever e caracterizar a tendência dos padrões melódicos de frases sob a incidência de marcadores prosódicos produzidas por leitores ainda em processo de aquisição de leitura, leitores em séries mais avançadas e leitores com nível superior de escolaridade.

A análise dos dados subsidiada nos pressupostos teóricos apresentados por Moraes (1998, 1993), Fry (1976), t'Hart, Collier e Cohen (1990), Scarpa (1999) acerca da percepção de F0 e sua importância para a entoação, sobretudo no que tange à distinção de modalidades de frases. 


\section{Resultados e discussões}

\subsection{As estratégias prosódicas em situação de coincidência e não coincidência entre MPL e MPG: uma análise acústica}

Nosso objetivo, aqui, foi analisar as estratégias prosódicas em situação de leitura de coincidência e não coincidência entre MPL e MPG. Com esse procedimento apresentamos mais um parâmetro para análise de fluência de leitura, que está relacionada ao planejamento prosódico.

\subsubsection{Condição experimental MPL/Perguntou + frases-alvo + MPG}

Nosso objetivo, aqui, é analisar as estratégias prosódicas em situação de leitura de coincidência e não coincidência entre MPL e MPG. Com esse procedimento seremos capazes de trazer mais um parâmetro para análise de fluência de leitura, que está relacionada ao planejamento prosódico.

São apresentados na tabela 1 os resultados para as frases-alvo introduzidas pelo Marcador Prosódico Lexical "perguntou" e finalizadas pelos Marcador Prosódico Gráfico (?) ponto de interrogação.

TABELA 1 - Valores médios da F0 (Hz) das sílabas tônicas realizadas pelos participantes (1, 2, 3 e 4 do grupo I); (5, 6. 7 e 8 do grupo II); (9, 10, 11 e 12 do grupo III) para as frases introduzidas pelo MPL "perguntou" e finalizadas pelo MPG ponto de interrogação (?).

\begin{tabular}{c|c|c|c|c|c|c}
\hline MPG & \multicolumn{7}{|c}{ MPL/PERGUNTOU } \\
\hline$?$ & 1 st & 2 st & 3 st & 4 st & 5 st & P \\
\hline INF 1 & 272.8750 & 285.2500 & 277.8833 & 250.2083 & 231.2083 & $0.0073^{\mathrm{s}}$ \\
\hline INF 2 & 323.4917 & 293.5917 & 265.4750 & 239.3750 & 338.5500 & $<0.0001^{\mathrm{s}}$ \\
\hline INF 3 & 246.7417 & 217.6592 & 247.0417 & 210.6333 & 260.9833 & $0.0307^{\mathrm{s}}$ \\
\hline INF 4 & 238.5500 & 236.7500 & 229.7000 & 185.1783 & 232.0167 & $0.0209^{\mathrm{s}}$ \\
\hline INF 5 & 245.9833 & 266.1250 & 265.9583 & 221.7333 & 213.2000 & $0.0005^{\mathrm{s}}$ \\
\hline INF 6 & 273.4167 & 224.6250 & 269.9167 & 199.8167 & 272.2000 & $0.0003^{\mathrm{s}}$ \\
\hline INF 7 & 168.8608 & 203.1417 & 192.6417 & 166.4500 & 239.4500 & $<0.0001^{\mathrm{s}}$ \\
\hline INF 8 & 155.3875 & 116.6108 & 149.2000 & 123.9942 & 166.8833 & $0.0005^{\mathrm{s}}$ \\
\hline
\end{tabular}




\begin{tabular}{c|c|c|c|c|c|c}
\hline INF 9 & 172.5250 & 153.6667 & 149.8167 & 154.8417 & 202.8000 & $<0.0001^{\mathrm{s}}$ \\
\hline INF 10 & 268.1000 & 220.5083 & 267.2167 & 200.3917 & 265.0000 & $0.0002^{\mathrm{s}}$ \\
\hline INF 11 & 294.1333 & 246.8667 & 232.2758 & 226.6092 & 298.2917 & $0.0619^{\text {ns }}$ \\
\hline INF 12 & 132.6142 & 130.7600 & 156.1250 & 122.2492 & 158.3833 & $0.0121^{\mathrm{s}}$ \\
\hline
\end{tabular}

Obs: s: significativo para $\alpha=\leq 0,05$; ns: não significativo para $\alpha=>0,05$. 3: MPG: marcador prosódico gráfico; MPL: marcador prosódico lexical; st: sílaba tônica; S/P: sem pontuação; INF: informante.

Para esta combinação, temos dois estímulos que remetem à carga prosódica interrogativa: o marcador prosódico lexical "perguntou" e o marcador prosódico gráfico (o ponto de interrogação). Desse modo, as frases afirmativas vão se diferenciar das frases interrogativas quanto às variações das curvas melódicas: enquanto as frases interrogativas apresentam padrões melódicos ascendentes - em que as frequências aumentam ao longo da sentença.

Como mostram os dados dispostos na tabela 1, os participantes de todos os grupos recuperaram o padrão entoacional ascendente, típicos de frases interrogativas. As curvas melódicas encontradas para as frasesalvo lidas pelos participantes evidenciam configuração final caracterizada por um movimento ascendente. De um modo geral, observamos que as curvas apresentam-se em pontos mais baixos logo antes da sílaba tônica final para, em seguida, apresentar proeminência na parte final, onde se localiza a sílaba tônica final.

As médias encontradas para os valores de F0 das sílabas tônicas foram submetidos ao teste estatístico ANOVA de Kruskal Wallis. Encontramos valores estatisticamente diferentes entre as médias das frases lidas por todos os participantes, exceto para o 11.

Observamos que, para a combinação de (perguntou + ?) dessa condição experimental 1, em que há coincidência entre o padrão prosódico do marcador que introduziu a frase e o marcador que as finalizou, o padrão melódico das sentenças assemelha com um dos padrões interrogativos descritos por Moraes (1998) - o padrão de dupla ascendência - típico de perguntas retóricas sim ou não, pedidos, enunciados em início de diálogo, nos quais as informações são consideradas novas . Percebese, de um modo geral, para todos os participantes, proeminência de F0 
sobre as sílabas tônicas iniciais, e um novo pico acontece sobre a sílaba tônica final.

Apresentamos na tabela 2 os resultados para as frases-alvo introduzidas pelo Marcador Prosódico Lexical "perguntou" e finalizadas pelos Marcador Prosódico Gráfico (...) reticências.

TABELA 2 - Valores médios da F0 (Hz) das sílabas tônicas realizadas pelos participantes (1, 2, 3 e 4 do grupo I); (5, 6. 7 e 8 do grupo II); (9, 10, 11 e 12 do grupo III) para as frases introduzidas pelo MPL "perguntou" e finalizadas pelo MPG reticências (...).

\begin{tabular}{c|c|c|c|c|c|c}
\hline MPG & \multicolumn{7}{c}{ MPL/PERGUNTOU } \\
\hline$\ldots$ & 1 st & 2 st & 3 st & 4 st & 5 st & P \\
\hline INF 1 & 287.1167 & 274.1250 & 253.6333 & 242.0167 & 283.3000 & $0.0123 \mathrm{~s}$ \\
\hline INF 2 & 328.9750 & 294.0750 & 264.5583 & 252.7417 & 300.1417 & $0.0101^{\mathrm{s}}$ \\
\hline INF 3 & 278.1917 & 229.0500 & 217.4592 & 205.1350 & 290.5250 & $0.0010^{\mathrm{s}}$ \\
\hline INF 4 & 239.0000 & 219.6000 & 217.1167 & 180.8833 & 254.5250 & $0.0032^{\mathrm{s}}$ \\
\hline INF 5 & 252.1833 & 238.9333 & 247.8250 & 206.0917 & 267.3333 & $0.0051^{\mathrm{s}}$ \\
\hline INF 6 & 275.4500 & 251.5917 & 254.8917 & 197.4500 & 252.2333 & $0.0019^{\mathrm{s}}$ \\
\hline INF 7 & 187.5383 & 201.1667 & 196.8750 & 173.2542 & 219.6750 & 0.1481 \\
\hline INF 8 & 132.1375 & 123.4642 & 110.8067 & 130.1683 & 189.6667 & $0.0003^{\mathrm{s}}$ \\
\hline INF 9 & 169.1583 & 156.7083 & 169.2083 & 170.3500 & 220.9250 & $0.0002^{\mathrm{s}}$ \\
\hline INF 10 & 256.4000 & 236.5250 & 242.8750 & 189.6083 & 263.4833 & $0.0003^{\mathrm{s}}$ \\
\hline INF 11 & 281.3417 & 237.6417 & 242.6250 & 216.4667 & 246.1667 & $0.1370^{\text {ns }}$ \\
\hline INF 12 & 141.5450 & 161.3250 & 151.2442 & 125.0033 & 172.3583 & $0.0052^{\mathrm{s}}$ \\
\hline
\end{tabular}

Obs: s: significativo para $\alpha=\leq 0,05$; ns: não significativo para $\alpha=>0,05$. 3: MPG: marcador prosódico gráfico; MPL: marcador prosódico lexical; st: sílaba tônica; S/P: sem pontuação; INF: informante.

Para essa combinação, temos o que é denominado mismatch (desencontro entre informações vindas de dois ou mais estímulos). $\mathrm{O}$ marcador prosódico lexical "perguntou" indica ao leitor que o padrão entoacional a ser seguido é o interrogativo, enquanto as reticências indicam um tom suspensivo (incompletude) e, conforme dados 
encontrados por Pacheco (2003), esse sinal de pontuação desencadeia contorno melódico nivelado, sem alterações na curva entoacional. Sendo assim, os informantes poderiam privilegiar qualquer um dos marcadores prosódicos durante a leitura. Embora não tenha sido possível distinguir os grupos quanto à fluência observando o seu comportamento prosódico nessa combinação experimental, verificamos que os leitores mais escolarizados, diante da situação mismatch, retomavam a leitura, no sentido de correção e, por fim, priorizaram o padrão interrogativo. Esse comportamento não foi observado no grupo I, composto por leitores das séries iniciais.

Verificamos padrão ascendente na leitura de todos os informantes, mesmo para os leitores menos escolarizados. Como mostram os dados dispostos na tabela 2, os participantes de todos os grupos recuperaram o padrão entoacional ascendente, típicos de frases interrogativas. Os valores de F0 encontrados para as frases-alvo lidas pelos participantes evidenciam configuração final caracterizada por um movimento ascendente. Embora a frase estivesse finalizada pelo ponto de reticências (...) que sugere padrão melódico nivelado ou descendente, o que percebemos é que todos os participantes mantiveram o padrão prosódico ascendente incitado pelo Marcador Prosódico Lexical "perguntou". De um modo geral, observamos que as curvas apresentam-se em valores mais baixos logo antes do contorno final para, em seguida, apresentar proeminência na parte final, onde se localiza a sílaba tônica final.

O teste ANOVA de Kruskal Wallis atestou, para todos os informantes, diferenças significativas entre as médias encontradas para as sílabas tônicas. Apenas para o participante 11 não foram encontradas diferenças significativas entre as médias das sílabas tônicas. 
TABELA 3 - Valores médios da F0 (Hz) das sílabas tônicas realizadas pelos participantes (1, 2, 3 e 4 do grupo I); (5, 6. 7 e 8 do grupo II); (9, 10, 11 e 12 do grupo III) para as frases introduzidas pelo MPL "perguntou" e finalizadas pelo MPG ponto de exclamação (!).

\begin{tabular}{c|c|c|c|c|c|c}
\hline MPG & \multicolumn{7}{c}{ MPL/PERGUNTOU } \\
\hline ! & 1 st & 2 st & 3 st & 4 st & 5 st & P \\
\hline INF 1 & 274.2333 & 257.2500 & 246.5983 & 217.3250 & 283.7167 & $0.0836^{\text {ns }}$ \\
\hline INF 2 & 319.8833 & 289.1083 & 265.1417 & 247.1000 & 336.2583 & $0.0002^{\mathrm{s}}$ \\
\hline INF 3 & 275.6500 & 242.7917 & 239.9583 & 210.1833 & 272.6333 & $0.0088^{\mathrm{s}}$ \\
\hline INF 4 & 241.6833 & 222.2083 & 208.7958 & 184.8050 & 255.3083 & $0.0218^{\mathrm{s}}$ \\
\hline INF 5 & 269.8833 & 244.6000 & 249.1000 & 222.2167 & 277.5833 & $0.0019^{\mathrm{s}}$ \\
\hline INF 6 & 266.1333 & 231.3750 & 264.6750 & 193.1417 & 245.4833 & $0.0029^{\mathrm{s}}$ \\
\hline INF 7 & 182.4750 & 196.6000 & 200.7333 & 176.2917 & 229.9500 & $0.4523^{\mathrm{ns}}$ \\
\hline INF 8 & 156.5300 & 137.6908 & 157.1167 & 125.3483 & 199.8083 & $0.0011^{\mathrm{s}}$ \\
\hline INF 9 & 159.2750 & 164.6167 & 162.2250 & 144.3917 & 198.7250 & $0.0017^{\mathrm{s}}$ \\
\hline INF 10 & 273.4833 & 244.6500 & 266.2583 & 201.7333 & 276.4750 & $0.0004^{\mathrm{s}}$ \\
\hline INF 11 & 263.2000 & 279.0000 & 254.1275 & 242.1917 & 286.5500 & $0.0105^{\mathrm{s}}$ \\
\hline INF 12 & 127.0958 & 152.9950 & 149.0667 & 124.4908 & 169.1167 & $0.0075^{\mathrm{s}}$ \\
\hline
\end{tabular}

Obs: s: significativo para $\alpha=\leq 0,05$; ns: não significativo para $\alpha=>0,05$. 3: MPG: marcador prosódico gráfico; MPL: marcador prosódico lexical; st: sílaba tônica; S/P: sem pontuação; INF: informante.

Como mostram os dados dispostos na tabela 3 , também para essa combinação com mismatch (desencontro entre as informações prosódicas dos dois marcadores - perguntou e ponto de exclamação), os informantes de todos os grupos recuperaram o padrão entoacional ascendente, típicos de frases interrogativas. Os valores de F0 encontrados para as frases-alvo lidas evidenciam configuração final caracterizada por um movimento ascendente. Apesar de as frases tiverem sido finalizadas pelo ponto de exclamação (!) que sugere padrão melódico descendente, verificamos que todos os participantes mantiveram o padrão prosódico ascendente incitado pelo marcador prosódico lexical "perguntou". Vemos que os valores mais baixos de F0 encontram-se na penúltima sílaba tônica, antes do contorno final para, em seguida, apresentar proeminência na parte final, onde se localiza a sílaba tônica final. 
Encontramos valores médios da F0 estatisticamente diferentes entre si entre as sílabas tônicas das frases para todos os informantes, exceto para os informantes 1 e 7 .

TABELA 4 - Valores médios da F0 (Hz) das sílabas tônicas realizadas pelos participantes (1, 2, 3 e 4 do grupo I); (5, 6. 7 e 8 do grupo II); $(9,10,11$ e 12 do grupo III) para as frases introduzidas pelo MPL "perguntou" e finalizadas pelo MPG ponto final (.).

\begin{tabular}{c|c|c|c|c|c|c}
\hline MPG & \multicolumn{7}{c}{ MPL/PERGUNTOU } \\
\hline & 1 st & 2 st & 3 st & 4 st & 5 st & P \\
\hline INF 1 & 286.9167 & 274.8083 & 285.3333 & 236.1500 & 297.3583 & $0.0010^{\mathrm{s}}$ \\
\hline INF 2 & 301.7083 & 279.0333 & 258.5167 & 211.4083 & 307.4167 & $0.0024^{\mathrm{s}}$ \\
\hline INF 3 & 255.4500 & 269.1917 & 237.0000 & 220.4667 & 302.7583 & $0.0018^{\mathrm{s}}$ \\
\hline INF 4 & 320.9000 & 219.5333 & 210.5250 & 170.5917 & 255.8133 & $0.0006^{\mathrm{s}}$ \\
\hline INF 5 & 239.8250 & 208.2083 & 215.7417 & 198.8250 & 269.1583 & $0.0002^{\mathrm{s}}$ \\
\hline INF 6 & 276.5750 & 248.6167 & 237.0500 & 189.2917 & 282.1967 & $0.0002^{\mathrm{s}}$ \\
\hline INF 7 & 186.3058 & 197.2750 & 197.9667 & 174.2500 & 232.8500 & $0.0467^{\mathrm{s}}$ \\
\hline INF 8 & 136.5258 & 124.5725 & 128.7025 & 117.0175 & 149.5167 & $0.4858^{\mathrm{ns}}$ \\
\hline INF 9 & 170.9500 & 153.8500 & 164.7500 & 151.9083 & 218.5250 & $<0.0001^{\mathrm{s}}$ \\
\hline INF 10 & 254.3833 & 241.9250 & 242.1583 & 185.6500 & 267.8667 & $0.0005^{\mathrm{s}}$ \\
\hline INF 11 & 285.1083 & 251.2417 & 257.7250 & 247.7250 & 289.0167 & $0.0082^{\mathrm{s}}$ \\
\hline INF 12 & 125.1767 & 146.0125 & 145.0375 & 140.4333 & 154.6417 & $0.4463^{\mathrm{ns}}$ \\
\hline
\end{tabular}

Obs: s: significativo para $\alpha=\leq 0,05$; ns: não significativo para $\alpha=>0,05.3$ : MPG: marcador prosódico gráfico; MPL: marcador prosódico lexical; st: sílaba tônica; S/P: sem pontuação; INF: informante.

Para essa combinação apresentamos também dois marcadores prosódicos: o marcador prosódico lexical "perguntou", cuja carga semântica remete às variações prosódicas de interrogação e o marcador prosódico gráfico (.) ponto final que, segundo Pacheco (2003), em se tratando da sua realização acústica, especificamente no que diz respeito ao parâmetro acústico F0, indica uma queda no componente pretônico e no componente tônico. Logo, as frases finalizadas pelo ponto de interrogação apresentam padrão descendente devido à redução da F0. 
Como é possível verificar na tabela 4, os valores de F0 das frases-alvo evidenciam padrão final ascendente na leitura realizada por todos os participantes. A informação prosódica do MPL "perguntou" foi suficiente para que os participantes entendessem que se tratava de uma frase interrogativa, ainda que o ponto final finalizasse a frase.

O teste ANOVA de Kruskal Wallis atestou diferenças significativas entre as médias das sílabas tônicas das frases-alvo na leitura de todos os informantes, excetuando os informantes 8 e 12 .

TABELA 5 - Valores médios da F0 (Hz) das sílabas tônicas realizadas pelos participantes (1, 2, 3 e 4 do grupo I); (5, 6. 7 e 8 do grupo II); (9, 10, 11 e 12 do grupo

III) para as frases introduzidas pelo MPL "perguntou" e sem pontuação ao final.

\begin{tabular}{c|c|c|c|c|c|c}
\hline MPG & \multicolumn{7}{c}{ MPL/PERGUNTOU } \\
\hline s/p & 1 st & 2 st & 3 st & 4 st & 5 st & P \\
\hline INF 1 & 291.2583 & 271.5000 & 244.7425 & 236.8000 & 286.4083 & $0.0004^{\mathrm{s}}$ \\
\hline INF 2 & 326.8083 & 272.3417 & 260.1000 & 236.4250 & 313.1500 & $<0.0001^{\mathrm{s}}$ \\
\hline INF 3 & 234.4517 & 269.0917 & 241.0333 & 198.8583 & 306.9583 & $<0.0001^{\mathrm{s}}$ \\
\hline INF 4 & 230.4083 & 213.8583 & 219.9500 & 196.9000 & 259.2167 & $0.0501^{\mathrm{ns}}$ \\
\hline INF 5 & 272.0750 & 252.4583 & 240.2750 & 225.2750 & 270.6833 & $0.0092^{\mathrm{s}}$ \\
\hline INF 6 & 299.2167 & 238.9833 & 259.0917 & 210.7833 & 266.8417 & $0.0336^{\mathrm{s}}$ \\
\hline INF 7 & 181.6417 & 201.4083 & 199.9417 & 179.0833 & 228.2775 & $0.0056^{\mathrm{s}}$ \\
\hline INF 8 & 124.2342 & 133.1975 & 143.6050 & 128.8608 & 185.0925 & $0.0307^{\mathrm{s}}$ \\
\hline INF 9 & 159.1833 & 164.0783 & 155.8333 & 162.2167 & 231.5000 & $0.0006^{\mathrm{s}}$ \\
\hline INF 10 & 253.0083 & 252.1750 & 250.0083 & 208.0083 & 275.5500 & $0.0071^{\mathrm{s}}$ \\
\hline INF 11 & 269.3333 & 237.7917 & 238.4917 & 258.6333 & 282.5333 & $0.0058^{\mathrm{s}}$ \\
\hline INF 12 & 120.4167 & 146.0675 & 138.1067 & 119.9133 & 168.8417 & $0.0211^{\mathrm{s}}$ \\
\hline
\end{tabular}

Obs: s: significativo para $\alpha=\leq 0,05$; ns: não significativo para $\alpha=>0,05$. 3: MPG: marcador prosódico gráfico; MPL: marcador prosódico lexical; st: sílaba tônica; S/P: sem pontuação; INF: informante.

Para as frases introduzidas pelo marcador prosódico lexical "perguntou" e sem pontuação ao final, os informantes foram expostos a apenas um estímulo prosódico no que se refere à entoação da modalidade da frase. Nesse tipo de condição experimental, um leitor fluente é capaz de se guiar pelo marcador prosódico inicial que lhe indica que a frase se 
trata de uma interrogativa. Assim, o mais natural seria encontrar, para essa combinação, padrão ascendente nos contornos melódicos, característicos de enunciados interrogativos.

Conforme é possível verificar na Tabela 5, o movimento de F0, na combinação MPL/perguntou + frases-alvo/sem pontuação, configurou-se da seguinte forma: valores altos de $\mathrm{F} 0$ associados às três primeiras sílabas tônicas, queda de F0 sobre a penúltima sílaba tônica e aumento significativo de F0 sobre a sílaba tônica final. O teste ANOVA atestou diferenças significativas entre as médias encontradas para essa combinação na leitura de todos os informantes, exceto para o informante 4.

\subsubsection{Condição experimental MPL/Disse + frases-alvo + MPG e MPL/Disse}

Para a condição experimental 2, em que as frases foram introduzidas pelo marcador prosódico lexical "disse" e finalizadas pelos diversos marcadores prosódicos gráficos, a saber ponto de interrogação (?), reticências (...), exclamação (!) e frases sem pontuação ao final não temos mismatch, e o que determinará o planejamento prosódico dos participantes é capacidade deles de gerenciar sua leitura a partir dos marcadores prosódicos que lhes serão apresentados. Como o marcador prosódico lexical "disse" é neutro do ponto de vista prosódico, ou seja, ele pode perfeitamente introduzir as mais diferentes modalidades de frases: interrogativas, afirmativas, exclamativas, imperativas etc.

Vejamos como foi o planejamento prosódico dos diferentes grupos diante da condição experimental 2 (MPL + frases-alvo + MPG; MPL + frases-alvo + frases sem pontuação ao final).

A Tabela 6 apresenta os resultados encontrados para as frases introduzidas pelo marcador prosódico lexical "disse" e finalizadas pelo marcador prosódico lexical ponto de interrogação (?). 
TABELA 6 - Valores médios da F0 (Hz) das sílabas tônicas realizadas pelos participantes (1, 2, 3 e 4 do grupo I); (5, 6. 7 e 8 do grupo II); (9, 10, 11 e 12 do grupo III) para as frases introduzidas pelo MPL "disse" e finalizadas pelo marcador prosódico gráfico ponto de interrogação (?).

\begin{tabular}{c|c|c|c|c|c|c}
\hline MPG & \multicolumn{6}{|c}{ MPL/DISSE } \\
\hline$?$ & 1 st & 2 st & 3 st & 4 st & 5 st & P \\
\hline INF 1 & 277.0167 & 260.3333 & 256.9933 & 256.1333 & 294.2000 & $0.0442^{\text {s }}$ \\
\hline INF 2 & 319.2833 & 280.8333 & 271.1667 & 254.7417 & 335.6083 & $0.0002^{\text {s }}$ \\
\hline INF 3 & 263.2833 & 261.0333 & 234.7667 & 200.8917 & 226.2525 & $0.0086^{\text {s }}$ \\
\hline INF 4 & 232.2333 & 214.0000 & 208.4500 & 187.6333 & 254.2833 & $0.0073^{\text {s }}$ \\
\hline INF 5 & 248.5833 & 217.2500 & 248.4750 & 198.6833 & 264.2917 & $0.0138^{\text {s }}$ \\
\hline INF 6 & 278.7333 & 222.6250 & 232.2917 & 204.8583 & 269.3667 & $0.0574^{\text {ns }}$ \\
\hline INF 7 & 186.3250 & 195.1667 & 194.0167 & 170.6167 & 200.8933 & $0.4575^{\text {ns }}$ \\
\hline INF 8 & 125.2533 & 124.2983 & 124.9483 & 110.4317 & 157.1250 & $0.0016^{\text {s }}$ \\
\hline INF 9 & 153.1917 & 132.0192 & 140.3667 & 137.8750 & 174.2750 & $0.0013^{\text {s }}$ \\
\hline INF 10 & 227.3167 & 208.9667 & 218.1250 & 175.3333 & 260.6667 & $<0.0001^{\text {s }}$ \\
\hline INF 11 & 281.1667 & 253.9250 & 253.1667 & 247.5333 & 266.0333 & $0.4905^{\text {ns }}$ \\
\hline INF 12 & 137.5650 & 129.5550 & 146.5342 & 135.4842 & 180.0833 & $0.0099^{\text {s }}$ \\
\hline
\end{tabular}

Obs: s: significativo para $\alpha=\leq 0,05$; ns: não significativo para $\alpha=>0,05$. 3: MPG: marcador prosódico gráfico; MPL: marcador prosódico lexical; st: sílaba tônica; S/P: sem pontuação; INF: informante.

Conforme os dados dispostos na tabela 6, os valores de F0 encontrados para as frases-alvo lidas por todos os participantes dos grupos I, II e III revelam padrão ascendente na parte final da frase onde se localizam as sílabas tônicas finais. Os valores de F0 mensurados revelam padrão melódico ascendente associado às sílabas tônicas, sobretudo sobre a sílaba tônica final. O padrão interrogativo desencadeado pelo marcador prosódico gráfico é resgatado por todos os participantes. Nesse caso, a presença do marcador prosódico gráfico ponto de interrogação (?) justifica o padrão melódico típico de interrogativas. Conforme evidencia Pacheco (2003), o ponto de interrogação é caracterizado, acusticamente, pelo aumento da F0 no componente tônico. Assim, o padrão encontrado para 
as frases-alvo produzidas pelos participantes dos grupos aqui investigados foi compatível com os MPLs e os MPGs que incidiram sobre as frases.

O teste ANOVA de Kruskal Wallis não atestou diferenças significativas entre as médias encontradas para as frases lidas pelos informantes 6, 7, 11 e 12. Contudo, diferenças significativas foram encontradas entre as médias das frases lidas pelos demais participantes.

TABELA 7 - Valores médios da F0 (Hz) das sílabas tônicas realizadas pelos participantes (1, 2, 3 e 4 do grupo I); (5, 6.7 e 8 do grupo II); $(9,10$, 11 e 12 do grupo III) para as frases introduzidas pelo MPL "disse" e finalizadas pelo MPG reticências (...).

\begin{tabular}{c|c|c|c|c|c|c}
\hline MPG & \multicolumn{7}{c}{ MPL/DISSE } \\
\hline$\ldots$ & 1 st & 2 st & 3 st & 4 st & 5 st & P \\
\hline INF 1 & 287.4250 & 270.2667 & 251.0083 & 234.7667 & 257.6500 & $0.0727^{\mathrm{ns}}$ \\
\hline INF 2 & 341.7750 & 285.5500 & 277.4667 & 244.1833 & 359.2833 & $<0.0001^{\mathrm{s}}$ \\
\hline INF 3 & 235.0375 & 238.6583 & 230.3033 & 210.0733 & 281.0000 & $0.0996^{\mathrm{ns}}$ \\
\hline INF 4 & 208.2133 & 220.3500 & 238.4417 & 186.0017 & 272.6250 & $0.0393^{\mathrm{s}}$ \\
\hline INF 5 & 251.7833 & 238.0833 & 203.6000 & 204.4333 & 155.9250 & $0.0053^{\mathrm{s}}$ \\
\hline INF 6 & 249.7750 & 227.8650 & 245.2000 & 203.0667 & 167.7500 & $0.0001^{\mathrm{s}}$ \\
\hline INF 7 & 163.9700 & 195.0500 & 190.7000 & 177.4083 & 165.3167 & $0.0501^{\mathrm{ns}}$ \\
\hline INF 8 & 137.1500 & 126.2500 & 139.2483 & 118.1008 & 118.9050 & $0.4242^{\mathrm{ns}}$ \\
\hline INF 9 & 146.6917 & 137.3583 & 142.1917 & 128.5833 & 124.5750 & $0.0335^{\mathrm{s}}$ \\
\hline INF 10 & 235.6917 & 217.9000 & 203.9167 & 170.9417 & 152.0000 & $<0.0001^{\mathrm{s}}$ \\
\hline INF 11 & 252.7417 & 246.2583 & 224.9908 & 214.2750 & 161.8008 & $0.0006^{\mathrm{s}}$ \\
\hline INF 12 & 134.7567 & 140.7742 & 128.9300 & 139.0175 & 132.8200 & $0.3747^{\mathrm{ns}}$ \\
\hline
\end{tabular}

Obs: s: significativo para $\alpha=\leq 0,05$; ns: não significativo para $\alpha=>0,05$. 3: MPG: marcador prosódico gráfico; MPL: marcador prosódico lexical; st: sílaba tônica; $\mathrm{S} / \mathrm{P}$ : sem pontuação; INF: informante

Os dados da tabela 7 revelam padrão final ascendente nos valores de F0 encontrados para as frases-alvo lidas pelos participantes do grupo I. Contudo, não há nenhuma justificativa para que a frase seja entendida como sendo uma interrogativa, já que o nem marcador prosódico 
lexical "disse" tampouco o marcador prosódico gráfico reticências (...) sugere padrão interrogativo. Já os valores d F0 das frases-alvo lidas pelos participantes dos grupos II e III configuram-se com padrão descendente. Conforme Pacheco (2003), as reticências são caracterizadas acusticamente pela queda da F0 no componente tônico das frases sob o seu escopo. Sendo assim, as frases sob incidência desse sinal de pontuação devem apresentar ou contorno nivelado, sem alterações significativas de elevação e abaixamento da F0, ou padrão final descendente, ocasionado pela redução da F0, como ocorre em enunciados declarativos. Portanto, também nesse caso, percebemos que os participantes mais escolarizados foram capazes de administrar acertadamente as variações melódicas e entoacionais desencadeadas pelos diferentes marcadores prosódicos se comparados aos participantes do grupo I (menos escolarizados).

Diferenças significativas não foram encontradas para as médias das sílabas tônicas das frases lidas pelos informantes 1, 3, 7, 8 e 12. Mas o teste ANOVA de Kruskal Wallis atestou diferenças significativas entre as médias encontradas na leitura dos demais informantes.

Os participantes do grupo I leram a frase-alvo com entoação típica de interrogativa, como é possível visualizarmos o padrão ascendente, mesmo não havendo nenhuma justificativa para tal, uma vez que nem o marcador prosódico lexical nem o marcador prosódico gráfico que introduziram e finalizaram a frase remetem ao padrão interrogativo. Por outro lado, os participantes dos grupos II e III procederam adequadamente com as variações entoacionais típicas dos marcadores prosódicos "disse" e as reticências. 
TABELA 8 - Valores médios da F0 (Hz) das sílabas tônicas realizadas pelos participantes (1, 2, 3 e 4 do grupo I); (5, 6. 7 e 8 do grupo II); (9, 10, 11 e 12 do grupo III) para as frases introduzidas pelo MPL "disse" e finalizadas pelo MPG ponto de exclamação (!).

\begin{tabular}{c|c|c|c|c|c|c}
\hline MPG & \multicolumn{6}{c}{ MPL/DISSE } \\
\hline ! & 1 st & 2 st & 3 st & 4 st & 5 st & P \\
\hline INF 1 & 283.1333 & 268.1000 & 274.5583 & 238.9417 & 255.4833 & $0.2487^{\text {ns }}$ \\
\hline INF 2 & 325.4400 & 281.1917 & 267.4417 & 219.6583 & 332.3750 & $<0.0001^{\mathrm{s}}$ \\
\hline INF 3 & 288.9250 & 230.9042 & 245.9333 & 215.0583 & 260.8017 & $0.0129^{\mathrm{s}}$ \\
\hline INF 4 & 245.4917 & 213.5333 & 226.4833 & 187.2250 & 266.8417 & $0.0026^{\mathrm{s}}$ \\
\hline INF 5 & 258.2083 & 213.4900 & 248.2417 & 206.0667 & 177.6667 & $<0.0001^{\mathrm{s}}$ \\
\hline INF 6 & 246.7333 & 236.9333 & 234.7000 & 203.7083 & 164.0075 & $<0.0001^{\mathrm{s}}$ \\
\hline INF 7 & 160.8067 & 191.8333 & 200.4167 & 169.5583 & 156.0750 & $0.0071^{\mathrm{s}}$ \\
\hline INF 8 & 146.7467 & 132.4458 & 141.1167 & 135.3350 & 123.8400 & $0.6588^{\mathrm{ns}}$ \\
\hline INF 9 & 146.2167 & 149.8583 & 142.8167 & 146.5750 & 122.9500 & $0.0503^{\mathrm{ns}}$ \\
\hline INF 10 & 235.8833 & 225.0333 & 193.1417 & 169.2417 & 134.1833 & $<0.0001^{\mathrm{s}}$ \\
\hline INF 11 & 255.9000 & 246.5275 & 259.1842 & 244.0250 & 219.6192 & $0.4965^{\text {ns }}$ \\
\hline INF 12 & 134.2625 & 151.8242 & 133.9517 & 141.2058 & 141.7700 & $0.5157^{\mathrm{ns}}$ \\
\hline IN
\end{tabular}

Obs: s: significativo para $\alpha=\leq 0,05$; ns: não significativo para $\alpha=>0,05$. 3: MPG: marcador prosódico gráfico; MPL: marcador prosódico lexical; st: sílaba tônica; $\mathrm{S} / \mathrm{P}$ : sem pontuação; INF: informante

Nas frases-alvo introduzidas pelo MPL "disse" e finalizada pelo ponto de exclamação (!), produzidas pelos participantes do grupo I, visualizamos as seguintes características: valores mais altos de F0 são encontrados na parte inicial da frase. A seguir, na parte intermediária, são vistos pontos mais baixos e, na parte final, onde está localizada a sílaba tônica final vemos outro pico da curva melódica. Essa configuração ascendente é típica de enunciados interrogativos. Ao contrário do que acontece com as curvas melódicas da frase lida pelos participantes do grupo I, os valores de F0 encontrados para as frases lida pelos participantes dos grupos II e III apresentam pontos mais baixos na parte final da frase, caracterizando um movimento descendente, característicos de enunciados 
afirmativos e exclamativos. O padrão prosódico mais adequado diante da leitura de frases finalizadas pelo ponto de exclamação é o descendente, pois, conforme comprovou Pacheco (2003), em se tratando da F0, a realização acústica desse sinal de pontuação apresenta aumento do componente tônico e queda no componente tônico, exatamente o que percebemos nas frases lidas pelos participantes dos grupos II e III.

Os valores de F0 das frases-alvo lidas pelos participantes do grupo I, expostas na tabela 8, apresentaram picos altos no início do contorno que caem ao longo da sentença e, ao final do enunciado, voltam a apresentar picos altos. $\mathrm{O}$ esperado para sentenças finalizadas pelo ponto de exclamação é uma queda da F0 no fim do enunciado o que ocasionaria uma curva descendente. Diante dos resultados, observase que os participantes do grupo I, por estarem ainda em processo de escolarização, em estágios inicias de leitura, não são capazes de recuperar as características prosódicas específicas dos diferentes sinais de pontuação.

Diferenças estatisticamente diferentes entre as médias das sílabas tônicas das frases foram encontradas pelo teste ANOVA de Kruskal Wallis na leitura dos informantes $2,3,4,5,6,7$ e 10. Nas médias das sílabas tônicas das frases lidas pelos participantes 1, 8, 9 e 12 não foram atestadas diferenças significativas.

TABELA 9 - Valores médios da F0 (Hz) das sílabas tônicas realizadas pelos participantes (1, 2, 3 e 4 do grupo I); (5, 6, 7 e 8 do grupo II); (9, 10, 11 e 12 do grupo III) para as frases introduzidas pelo MPL "disse" e finalizadas pelo MPG ponto final (.).

\begin{tabular}{c|c|c|c|c|c|c}
\hline MPG & \multicolumn{7}{c}{ MPL/DISSE } \\
\hline & $1 \mathrm{st}$ & $2 \mathrm{st}$ & $3 \mathrm{st}$ & $4 \mathrm{st}$ & $5 \mathrm{st}$ & $\mathrm{P}$ \\
\hline INF 1 & 280.2000 & 278.6500 & 282.7000 & 227.5500 & 266.0667 & $0.0568^{\mathrm{ns}}$ \\
\hline INF 2 & 306.3667 & 271.3250 & 282.0667 & 257.0667 & 297.6250 & $0.0394^{\mathrm{s}}$ \\
\hline INF 3 & 257.7250 & 224.2583 & 247.7750 & 212.5167 & 251.5583 & $0.0294^{\mathrm{s}}$ \\
\hline INF 4 & 246.0250 & 223.5500 & 214.4000 & 194.8333 & 244.4750 & $0.0097^{\mathrm{s}}$ \\
\hline INF 5 & 246.7167 & 192.9317 & 231.3750 & 174.7758 & 165.1750 & $0.0014^{\mathrm{s}}$ \\
\hline INF 6 & 252.8667 & 242.1250 & 271.6750 & 189.2925 & 168.8300 & $<0.0001^{\mathrm{s}}$ \\
\hline INF 7 & 187.7517 & 194.0233 & 189.7333 & 167.5667 & 156.1283 & $0.0194^{\mathrm{s}}$ \\
\hline
\end{tabular}




\begin{tabular}{l|c|c|c|c|c|c}
\hline INF 8 & 134.4233 & 121.0900 & 119.8083 & 155.9367 & 115.9567 & $0.0506^{\mathrm{ns}}$ \\
\hline INF 9 & 140.6750 & 142.2925 & 139.6333 & 133.8883 & 135.8417 & $0.6593^{\mathrm{ns}}$ \\
\hline INF 10 & 207.7917 & 216.1000 & 200.2667 & 161.9583 & 149.9250 & $<0.0001^{\mathrm{s}}$ \\
\hline INF 11 & 256.1642 & 227.6500 & 248.7833 & 204.8667 & 163.7008 & $0.0005^{\mathrm{s}}$ \\
\hline INF 12 & 122.0600 & 127.5258 & 152.5667 & 127.4275 & 132.6833 & $0.1847^{\mathrm{ns}}$ \\
\hline
\end{tabular}

Obs: s: significativo para $\alpha=\leq 0,05$; ns: não significativo para $\alpha=>0,05$. 3: MPG: marcador prosódico gráfico; MPL: marcador prosódico lexical; st: sílaba tônica; S/P: sem pontuação; INF: informante.

Para Cagliari (1989), os sinais de pontuação funcionam como marcadores prosódicos. Tal função é reafirmada por Cagliari (2002a, 2002b) ao descrever prosodicamente os principais sinais de pontuação do português brasileiro. Os trabalhos de Cagliari confirmam que a presença de um sinal de pontuação tende a incitar variações prosódicas. Os trabalhos de Pacheco $(2003,2006)$ endossam as considerações de Cagliari (1989, 2002a, 2002b) acerca dos marcadores prosódicos da escrita. Ao encontrar variações de F0, intensidade, duração e pausa nos componentes tônicos e pretônico nas frases sob incidência dos sinais de pontuação dois pontos, interrogação, ponto e vírgula, reticências, ponto final, exclamação e ponto final, a pesquisadora confirma que os sinais de pontuação podem ter características acústicas particulares, de modo a se diferenciarem entre si. Tratando, especificamente, do ponto final (marcador prosódico gráfico), caracteriza-se por apresentar queda de F0 no componente pretônico e no componente tônico nas frases sob sua incidência. (PACHECO, 2003). Como mostram os dados da tabela 9, os valores de F0 encontrados para as frases-alvo introduzidas pelo marcador prosódico lexical "disse" e finalizadas pelo ponto final (marcador prosódico gráfico), lidas pelos participantes dos grupos II e III visualizamos as características apontadas por Cagliari (1989, 2002a, 2002b) e Pacheco (2003). A configuração do contorno melódico é a de um enunciado afirmativo, apresentando contorno final descendente. O contrário é percebido nas curvas melódicas da frase-alvo lida pelos participantes do grupo I. Notamos contorno final ascendente (evidenciado pelo aumento da F0), prototípico de enunciados interrogativos. Os dados apresentados na Tabela 9, para os informantes 5, 6, 7, 8, 9, 10, 11 e 12, demonstram a configuração de curvas prototípicas de frases afirmativas 
ou exclamativas, caracterizadas por um contorno final descendente. $\mathrm{O}$ contorno final ascendente, encontrado para os informantes 1, 2, 3, e 4, demonstra que os participantes do grupo I não foram capazes de proceder adequadamente com os padrões melódicos e entoacionais desencadeados pelos diferentes marcadores prosódicos, já que o MPL “disse" não suscita contorno ascendente.

Diferenças significativas entre as médias das tônicas foram encontradas pelo teste ANOVA na leitura dos informantes 2, 3, 4, 5, $6,7,10$ e 11. Para os demais participantes as médias não diferiram estatisticamente entre si.

TABELA 10 - Valores médios da F0 (Hz) das sílabas tônicas realizadas pelos participantes (1, 2, 3 e 4 do grupo I); (5, 6. 7 e 8 do grupo II);

$(9,10,11$ e 12 do grupo III) para as frases introduzidas pelo MPL "disse" e finalizadas pelo MPG ponto final (.).

\begin{tabular}{c|c|c|c|c|c|c}
\hline MPG & \multicolumn{7}{c}{ MPL/DISSE } \\
\hline s/p & 1 st & 2 st & 3 st & 4 st & 5 st & P \\
\hline INF 1 & 281.1750 & 270.9667 & 267.2583 & 228.3500 & 267.9917 & $0.3127^{\mathrm{ns}}$ \\
\hline INF 2 & 339.5000 & 284.2500 & 270.0750 & 251.5500 & 320.5167 & $<0.0001^{\mathrm{s}}$ \\
\hline INF 3 & 262.8000 & 264.6000 & 265.6667 & 203.2083 & 277.9583 & $0.0014^{\mathrm{s}}$ \\
\hline INF 4 & 226.2917 & 206.7908 & 209.7333 & 189.3667 & 250.8000 & $0.0588^{\mathrm{ns}}$ \\
\hline INF 5 & 261.8750 & 250.6750 & 258.7333 & 199.8333 & 163.1500 & $<0.0001^{\mathrm{s}}$ \\
\hline INF 6 & 258.5167 & 234.4483 & 227.2500 & 206.0000 & 164.2667 & $<0.0001^{\mathrm{s}}$ \\
\hline INF 7 & 197.0750 & 196.0658 & 200.0583 & 168.1167 & 167.0050 & $0.0272^{\mathrm{s}}$ \\
\hline INF 8 & 149.4000 & 126.2792 & 153.2108 & 112.0117 & 119.7683 & $0.0330^{\mathrm{s}}$ \\
\hline INF 9 & 146.4667 & 155.5250 & 147.8417 & 136.6500 & 121.3183 & $0.1061^{\mathrm{ns}}$ \\
\hline INF 10 & 239.9500 & 238.1833 & 224.4750 & 210.5667 & 155.7917 & $0.0003^{\mathrm{s}}$ \\
\hline INF 11 & 197.4000 & 224.9500 & 225.4583 & 176.4667 & 142.7808 & $0.0036^{\mathrm{s}}$ \\
\hline INF 12 & 133.0283 & 150.3167 & 130.1350 & 128.5317 & 135.0358 & $0.4489 \mathrm{n}^{\mathrm{s}}$ \\
\hline
\end{tabular}

Obs: s: significativo para $\alpha=\leq 0,05$; ns: não significativo para $\alpha=>0,05$. 3: MPG: marcador prosódico gráfico; MPL: marcador prosódico lexical; st: sílaba tônica; S/P: sem pontuação; INF: informante. 
A Tabela 10 mostra os valores de F0 encontrados para as frases-alvo introduzidas pelo marcador prosódico lexical "disse" e sem pontuação ao final, lidas pelos informantes dos grupos II e III com configuração do contorno melódico de um enunciado afirmativo, apresentando contorno final descendente. Os valores de F0 das tônicas das frases-alvo lidas pelos informantes do grupo I evidenciaram contorno final ascendente (marcado pelo aumento da F0), prototípico de enunciados interrogativos. Os dados da Tabela 10 apontam que os informantes 5, $6,7,8,9,10,11$ e 12, realizaram a leitura das frases lançando mão de entonação compatível com frases afirmativas ou exclamativas, as quais apresentam um contorno final descendente. $\mathrm{O}$ contorno final ascendente, encontrado para os informantes $1,2,3$, e 4, pois encontramos valores mais altos de F0 incidindo sobre a sílaba tônica final.

Diferenças significativas entre as médias das tônicas foram encontradas pelo teste ANOVA na leitura dos informantes 2, 3, 5, 6, $7,10,11$ e 12. Para os demais participantes as médias não diferiram estatisticamente entre si.

Como o MPL "disse" pode introduzir as mais diferentes modalidades de frases e porque as frases-alvo nessa combinação não foram pontuadas ao final, os informantes poderiam apresentar qualquer padrão entoacional. O interessante foi o fato de os leitores mais escolarizados (grupo II e III) apresentarem padrão descendente, enquanto os menos escolarizados (grupo I) optaram pela leitura das frases em padrão interrogativo, assim como para todas as combinações das duas condições experimentais.

\section{Discussão}

A partir dos resultados encontrados para o grupo I - leitores em processo inicial de escolarização; grupo II - leitores em estágio mais avançado de escolarização; grupo III - leitores com nível superior completo, podemos fazer as seguintes considerações:

1. O comportamento entoacional das sentenças realizadas pelos participantes do grupo II e do grupo III, sob a condição experimental MPL/perguntou + frases-alvo + MPG (ou frasesalvo sem pontuação) e sob a combinação experimental MPL/disse + frases-alvo + MPG (ou frases-alvo sem pontuação) aproxima 
esses grupos no sentido de que o comportamento entoacional dos participantes desses grupos é modelado a depender da natureza do MPL que introduz a frase. Diante do MPL "perguntou" as frases-alvo produzidas pelos participantes do grupo II e III e do MPL configuraram-se com um padrão interrogativo. Quando diante do MPL "disse", o padrão melódico das mesmas frasesalvo produzidas por esses participantes só configurou-se como interrogativo quando as frases foram finalizadas pelo marcador prosódico gráfico ponto de interrogação. As combinações da condição experimental MPL/perguntou + frases-alvo + MPG mostraram que a presença do MPL "perguntou" foi suficiente para que os participantes do grupo II e do grupo III reconhecessem as sentenças como sendo interrogativas, mesmo quando elas foram finalizadas por um MPG cuja carga prosódica não remete a uma interrogação (nas condições de mismatch). Observamos que, diante de uma condição de mismatch, na qual o MPG que finaliza a frase não é compatível com o MPL "perguntou" que a introduz, os participantes do grupo II e do grupo III priorizam a informação prosódica do MPL "perguntou”, qual seja, padrão interrogativo.

2. Diante do MPL “disse", na condição experimental MPL/disse + frases-alvo + MPG, os participantes do grupo II e III apresentaram padrão ascendente na combinação MPL/disse + frases-alvo + MPG/ponto de interrogação. Nesse caso, o padrão interrogativo foi desencadeado pelo MPG “?”. Nas demais combinações nas quais não há a presença de um marcador prosódico que carrega informações prosódicas típicas de interrogativas, como o MPL o MPG “?”, o padrão que prevalece é o descendente, mais previsível para os MPGs ponto de exclamação, ponto final, reticências. Mesmo na combinação MPL/disse + frases-alvo/sem pontuação, o padrão que prevaleceu para esses participantes foi o descendente. Nas combinações MPL/disse + frases-alvo + MPG/ponto de exclamação; MPL/disse + frases-alvo + MPG/ponto final, o MPL disse neutraliza o acionamento da elevação da curva melódica, de modo que cabe ao leitor modular o enunciado de acordo com o padrão melódico correspondente aos MPGs que finalizam as sentenças, qual seja, padrão melódico descendente e, no caso da combinação MPL/disse + frases-alvo + MPG/reticências, padrão melódico nivelado ou descendente. Em se tratando da combinação 
MPL/disse + frases-alvo/sem pontuação, qualquer padrão melódico seria aceitável, já que não há a presença de nenhum marcador prosódico que suscite uma informação prosódica específica. O que acontece, nesse caso, é que o grupo II e o grupo III optam pelo padrão descendente, enquanto o grupo I mantêm o mesmo padrão ascendente das outras combinações.

Para as duas condições experimentais aqui investigadas 1 (frases introduzidas pelo MPL "perguntou" e finalizadas pelos MPGs “?”, “!”, “...”, “.” E frases sem pontuação ao final); 2 (frases introduzidas pelo MPL "disse" e finalizadas pelos MPGs "?", “!”, “...”, “.” E frases sem pontuação final), os informantes dos grupos II e III realizam as mesmas sentenças com contornos melódicos diferentes motivados apenas pela alternância entre os MPLs “perguntou" e "disse". O grupo I, por outro lado, apresenta o mesmo padrão entoacional para todas as frases-alvo.

3. O comportamento entoacional das frases-alvo lida pelos participantes do grupo I o aproxima dos grupos II e III nas sentenças realizadas sob a condição experimental MPL/ perguntou + frases + MPG. Entretanto, nas sentenças realizadas sob a condição experimental MPL/disse + frases-alvo + MPG, o distancia.

Com base nos resultados encontrados, observamos que, para as sentenças da condição experimental MPL perguntou + frases-alvo + MPG, os participantes do grupo I apresentam padrão ascendente, típico de interrogativas. Verificamos contorno final ascendente em todas as combinações dessa condição experimental. Contudo, para a condição experimental MPL/disse + frases-alvo + MPG, observa-se que os participantes do grupo I apresentaram padrão ascendente para todas as combinações.

Para as combinações da condição experimental MPL/perguntou + frases-alvo + MPG e para a combinação MPL/disse + frases-alvo + MPG/ ponto de interrogação, o padrão ascendente era previsível, uma vez que o MPL "perguntou", que introduz as sentenças da condição experimental $\mathrm{MPL} /$ perguntou + frases-alvo $+\mathrm{MPG}$, motiva o resgate da carga prosódica interrogativa, despontada na ascendência dos contornos finais das sentenças. No caso da combinação MPL/disse + frases-alvo + MPG/ ponto de interrogação, o próprio MPG/ponto de interrogação justifica a 
ascendência final das sentenças. Entretanto, para as combinações MPL/ disse + frases-alvo + MPG/reticências; MPL/disse + frases-alvo + MPG/ ponto de exclamação; MPL/disse + frases-alvo + MPG/ponto final, não há justificativa para a elevação final do contorno melódico. Diante disso, lançamos mão das seguintes hipóteses:

i) O fato de o padrão interrogativo ser o default da língua, isto é, as sentenças interrogativas são muito produtivas nas línguas, faz com que crianças em estágio inicial de aquisição de leitura produzam as sentenças com padrão interrogativo.

ii) O fato de o marcador prosódico "perguntou" ter uma carga prosódica muito forte, e sendo característico da linguagem oral - utilizado mais frequentemente em contexto de oralidade em situações comunicativas cotidianas - tenha causado um efeito de memória nos participantes do grupo I. Como as frases-alvos eram as mesmas para todas as combinações, é provável que o padrão interrogativo tenha ficado registrado (efeito de memória), de modo que, mesmo diante das frases sem a presença do MPL/perguntou e do MPG/?, os participantes apresentaram padrão interrogativo. Como indivíduos menos fluentes ainda não têm consciência plena quanto ao uso e funções dos sinais de pontuação, a carga prosódica do MPL perguntou prevaleceu sobre todas as sentenças. Contudo, seria necessária a realização de outro experimento que confirmasse as nossas hipóteses mencionadas acima. O fato é que, de qualquer modo, os resultados encontrados para o grupo I nos indicam que:

iii) Os participantes do grupo I não conseguem modelar o contorno entoacional das sentenças das combinações MPL/disse + frasesalvo + MPG/reticências; MPL/disse + frases-alvo + MPG/ponto de exclamação; MPL/disse + frases-alvo + MPG/ponto final de acordo com os diferentes sinais de pontuação, uma vez que há padrão ascendente das frases dessas combinações, mesmo sem a presença do MPL "perguntou” introduzindo as frases, ou do MPG/ponto de interrogação finalizando as frases. Como o MPL "disse" é neutro, não carrega informações prosódicas específicas, o padrão ascendente é incompatível com os MPGs que finalizam as frases dessas combinações. 


\section{Conclusões}

Os resultados encontrados para a caracterização do padrão acústico das sentenças introduzidas pelos MPLs "perguntou" e "disse" com respectivas frases sob a incidência dos MPGs (ponto de interrogação, reticências, ponto de exclamação, ponto final) e frases sem pontuação produzidas pelos participantes, mostraram que tanto o leitor com maior nível de escolaridade quanto o leitor com menor nível de escolaridade é capaz de proceder com variações melódicas e entoacionais compatíveis com enunciados interrogativos diante de frases introduzidas pelo marcador perguntou. Isso reforça a dupla natureza desse marcador (portador tanto de informações semânticas quanto prosódicas) que são captadas também por leitores menos experientes.

Contudo, diante de frases introduzidas pelo MPL "disse", verificamos que os participantes do grupo II e do grupo III, leitores mais escolarizados, procederam mais adequadamente com as variações entoacionais prototípicas dos MPGs que finalizaram as frases. Não encontramos diferenças significativas entre os dados da análise acústica do grupo II e do grupo III, o que aponta que o comportamento desses participantes foi semelhante nas duas condições experimentais às quais foram expostos.

Conforme os resultados obtidos, os leitores escolarizados conseguem resgatar mais adequadamente as variações entoacionais incitadas pelos diferentes marcadores gráficos e lexicais presentes no texto escrito.

O nosso trabalho confirma a hipótese de que o resgate de marcadores prosódicos gráficos e lexicais pode caracterizar leitores fluentes e não fluentes.

Os marcadores prosódicos da escrita fazem parte do sistema linguístico e contribuem para a atribuição de sentido ao texto. No processo de aquisição da leitura e da escrita, incorporamos essas marcas gráficas, assim como o sistema ortográfico, e a não consideração desses recursos gráficos e lexicais, na leitura de um texto, implicaria na falta de compreensão do texto na sua totalidade.

Nossas constatações sugerem que, no ensino da leitura e, consequentemente da escrita, nas tarefas de leitura e compreensão de texto, as questões prosódicas presentes no texto devem ser levadas em consideração. 


\section{Agradecimentos}

Aos participantes da pesquisa sem os quais a sua execução não seria possível.

À Universidade Estadual do Sudoeste da Bahia, em especial ao Laboratório de Pesquisa e Estudos em Fonética e Fonologia (LAPEFF) por nos fornecer a infraestrutura adequada à coleta de dados.

À Coordenação de Aperfeiçoamento de Pessoal de Nível Superior (CAPES) pelo subsídio financeiro à pesquisa.

\section{Contribuição das autoras}

Alcione de Jesus Santos: atuou na preparação do corpus para coleta de dados, na coleta de dados, bem como na seleção de referências bibliográficas e na mensuração e análise dos dados.

Vera Pacheco: atuou na seleção de referências bibliográficas, montagem do design experimental e na análise de dados, correção das análises e revisão geral do texto.

Marian dos Santos Oliveira: atuou na seleção de referências bibliográficas, montagem do design experimental e na revisão da análise de dados.

\section{Referências}

BALDWIN R. S.; COADY, J. M. Psycholinguistic Approaches to a Theory of Punctuation. Journal of Reading Behavior, Orlando, v. 10, n. 4, p. 363-375, 1978. Doi: https://doi.org/10.1080/10862967809547290

BREZNITZ, Z. Fluency in reading: synchonization of processes. Mahwah: Lawrence Elbaum Associates, 2006.

CAGLIARI, L. C. Marcadores prosódicos na escrita. In: SEMINÁRIO DO GRUPO DE ESTUDOS LINGUÍSTICOS, 18., 1989, Lorena. Anais [...] Lorena: Grupo de Estudos Linguísticos de São Paulo, 1989. p. 195-203.

CAGLIARI, L. C. Breve história da pontuação. In: CONGRESSO BRASILEIRO DE LINGUÍSTICA APLICADA, 4., 1995, Campinas. Anais [...], Campinas: Unicamp, 1995. p.177-183.

CAGLIARI, L.C. A estrutura prosódica do romance A Moreninha. 2002. 40f. Relatório (Estágio Pós-Doutoral) - Linacre College, University of Oxford, Oxford, 2002a. 
CAGLIARI, L. C. Prosody and Literature: A Case Study of Chapter I from Women in Love by D. J. Lawrence. 28f. Relatório (Estágio PósDoutoral) - Linacre College, University of Oxford, Oxford, 2002b.

CHACON, L. Ritmo da escrita: uma organização do heterogêneo da linguagem. São Paulo: Martins Fontes, 1998.

CHEN, H. C.; CHAN, K. T.; TSOI, K. C. Reading selfpaced moving text on a computer display. Human Factors, New York, v. 30, n. 3, p. 285-291, Jun. 1988. Doiu: https://doi.org/10.1177/001872088803000303

COHEN, H.; DOUAIRE, J.; ELSABBAGH, M. The role of prosody in discourse. Brain and Cognition, San Diego, v. 46, n. 1-2, p. 73-81, jun./ jul. 2001. Doi: https://doi.org/10.1016/S0278-2626(01)80038-5

CORRÊA, M. L. G. O modo heterogêneo de constituição da escrita. São Paulo: Martins Fontes, 2004.

FERREIRA, R. D. S. Avaliação da fluência na leitura em crianças com e sem necessidades educativas especiais: validação de uma prova de fluência na leitura para o $2^{\circ}$ ano do $1^{\circ}$ C. E. B. 2009. Dissertação (Mestrado em Educação Especial) - Faculdade de Motricidade Humana, Faculdade de Lisboa, Lisboa, 2009.

FÓNAGY, I. As funções modais da entonação. Cadernos de Estudos Linguísticos, Campinas, n. 25, p. 26-66, 1993.

FRY, D. B. Acoustic phonetics: a course of basic readings. Cambridge: Cambridge University Press, 1976.

FUSSEK, M. S. A influência de aspectos prosódicos na compreensão da linguagem oral e da leitura. 2009. Dissertação (Mestrado em Educação) - Universidade Federal do Paraná, Curitiba, 2009.

t'HART, J.; COLLIER, R.; COHEN, A. A perceptual study of intonation. Cambridge: Cambridge University Press, 1990. Doi: https://doi. org/10.1017/CBO9780511627743

HUDSON, R. F.; LANE, H. B.; PULLEN, P. C. Reading fluency assessment and instruction: What, why, and how? The Reading Teacher. Newark, v. 58, n. 8, p. 702-714, May 2005. Doi: https://doi.org/10.1598/ RT.58.8.1 
KONDO, T.; MAZUKA, R. Prosodic Planning While Reading Aloud: On-line Examination of Japanese Sentences. Journal of Psycholinguistic Research, Warsaw, v. 25, n. 2, p. 357-381, 1996. Doi: https://doi. org/10.1007/BF01708578

KUHN, M.; STAHAL, S. A. Fluency: a review of development and remedial practices. Journal of Educational Psychology, Tempe, Arizona, v. 95, p. 3-21, 2003. Doi: https://doi.org/10.1037/0022-0663.95.1.3

LEITE, C. T. A relação entre a compreensão e os aspectos prosódicos na leitura em voz alta de falantes do PE e do PB. 2012. 217f. Tese (Doutorado em Estudos Linguísticos) - Universidade Federal de Minas Gerais, Belo Horizonte, 2012.

MASSINI-CAGLIARI, G.; CAGLIARI, L. C. Fonética. In: MUSSALIM, F.; BENTES, A. C. Introdução à linguística: domínios e fronteiras. São Paulo: Cortez, 2001. v. 1, p. 105-146.

MATEUS, M. H. et al. Gramática da língua portuguesa. 2. ed. Lisboa: Caminho, 1994.

MATTOSO CÂMARA JR., Joaquim. Dicionário de Filologia e Gramática. 7. ed. Petrópolis: Vozes, 1977. 266p.

MORAES, J. A. A entoação modal brasileira: fonética e fonologia. Cadernos de Estudos Linguísticos, Campinas, v. 25, p.101-111, 1993.

MORAES, J. A. Intonation in Brazilian Portuguese. In: HIRST, D.; Di CRISTO, A. (ed.). Intonation Systems: a Survey of Twenty Languages, Cambridge: Cambridge University Press, 1998. p. 179-194.

PACHECO, V. Estudo dos marcadores prosódicos através de uma investigação acústico-perceptual de textos lidos por falantes do português do Brasil. 2003. 132f. Dissertação (Mestrado em Linguística) Instituto de Estudos da Linguagem, Universidade Estadual de Campinas, Campinas, 2003.

PACHECO, V. O efeito dos estímulos auditivo e visual na percepção dos marcadores prosódicos lexicais e gráficos usados na escrita do português brasileiro. 2006. 349f. Tese (Doutorado em Linguística) - Instituto de Estudos da Linguagem, Universidade Estadual de Campinas, Campinas, 2006. 
PACHECO, V. Evidências do funcionamento da língua oral no texto escrito. Intersecç̧ões, Jundiaí, v. 1, n. 1, p. 1-15, 2008.

QUILIS, A. Estudo Comparativo entre la Entonación Portuguesa (de Brasil) y la Española. Revista de Filosofia Española, Madrid, v. 68, p. 33-65, 1988. Doi: https://doi.org/10.3989/rfe.1988.v68.i1/2.412

REINECKE, K. Parâmetros acústicos de perguntas sim-não e Wh- no alemão e no português brasileiro. Revista Letras, Curitiba, v. 73, p. 47-71, 2007. Doi: https://doi.org/10.5380/rel.v73i0.8626

REIS, C. A entonação no ato de fala. In: MENDES, E.; OLIVEIRA, P.; BENNIBLER, V. (org.). O novo milênio: interfaces linguísticas e literárias. Belo Horizonte: Faculdade de Letras da UFMG, 2001. p. 221-229.

SCARPA, E.M. Sons preenchedores e guardadores de lugar: relações entre fatos sintáticos e fatos prosódicos. In: SCARPA, E. M. (org). Estudos de prosódia. Campinas: Editora da UNICAMP, 1999. p. 253-284.

SHREIBER, P. A. Understanding prosody's role in reading acquisition. Theory into Practise, v. 30, n. 3, p. 158-164, 1991. Doi: https://doi. org/10.1080/00405849109543496

SOUZA, K. K. Análise do fenômeno da declinação na entoação de sentenças declarativas isoladas dos falantes do Português Brasileiro. 2007. 144f. Dissertação (Mestrado em Linguística) - Universidade Federal de Minas Gerais, Belo Horizonte, 2007.

WENNERSTROM, A. The role of intonation in second language fluency. In H. Riggenbach (ed.). Perspectives on Fluency. Ann Arbor: Universidade de Michigan, 2000. p. 102-127. 